ECONOMICS

\title{
HOUSE PRICES, NON-FUNDAMENTAL COMPONENTS AND INTERSTATE SPILLOVERS: \\ THE AUSTRALIAN EXPERIENCE
}

by

Greg Costello
Curtin University of Technology

Patricia Fraser

Curtin University of Technology and University of Aberdeen

Nicolaas Groenewold Business School

The University of Western Australia 


\title{
HOUSE PRICES, NON-FUNDAMENTAL COMPONENTS AND INTERSTATE SPILLOVERS: THE AUSTRALIAN EXPERIENCE
}

\author{
by \\ Greg Costello \\ Curtin University of Technology \\ Patricia Fraser
}

Curtin University of Technology and University of Aberdeen

Nicolaas Groenewold

Business School

The University of Western Australia, 


\begin{abstract}
Using Australian capital city data from 1984Q3-2008Q2, this paper utilizes a dynamic present value model within a VAR framework to construct time series of house prices depicting what aggregate house prices should be given expectations of future real disposable income - the 'fundamental price' - and continues by comparing capital city fundamental prices with actual prices. The extent to which revealed capital city 'non-fundamental' components spillover from state to state, as well as their long-term impact is also investigated. Results provide evidence of periods of sustained deviations of house prices from values warranted by income for all state capitals with the greatest deviations arising in the NSW market and starting around 2000. In general NSW is relatively more susceptible to spillovers transmitted from other states while ACT and WA are most isolated from the rest of the country.
\end{abstract}

Key words: house prices, present value model, house price fundamentals, house price-income ratio, VAR/VEC modelling.

JEL Classification: R21 - Housing Demand, R31 - Housing Supply and Markets, G12 - Asset Pricing; Trading volume; Bond Interest Rates 


\section{Introduction}

In this era of the Global Financial Crisis (GFC) 2007-2009, reporting and analysis of housing market activity in the popular press and in academic circles has been a dominant theme. It is becoming evident that international housing markets have been impacted by the GFC in different ways. In the US it has been reported that 2009 began with record declines in house prices, (Standard \& Poor's, 2009). From year-end 2006 through the first quarter of 2009, real house prices in the US have fallen by 34\% (Campbell et al. 2009). Similar reports exist for many other developed economies. While in general there has been a decline in global real house prices, the patterns of price changes are not consistent. For example, Australia's major housing markets and general economy appear surprisingly resilient. In late 2009 Australia was the first of the G-20 economy to have raised official interest rates. Much of the commentary and some of the official dialogue surrounding monetary policy movements in Australia during this period reflect concerns of a pending house price bubble (Murdoch, 2009). This concern has been reinforced by the recent confirmation that house prices in Australia rose by $4.2 \%$ in the September quarter of 2009 (Australian Bureau of Statistics, 2009).

These recent events place an increasingly important emphasis on understanding house price activity and its relationship with the macro economy, not least because sustained misalignment of house prices with economic fundamentals is suggestive of economic and social instability driven by inefficient pricing. In a recent study of international house prices and macroeconomic fluctuations (Beltratti and Morana, 2009) raise some interesting questions as to whether there is a common global factor driving the cycle in international real estate prices. They point out that since the late 1990s, housing prices have been increasing at a very rapid pace in all G-7 countries, except for Japan. This house price growth has been achieved in an era of generally favourable macroeconomic conditions characterised by low nominal interest rates and inflation together with broad liquidity growth. In general, house prices in the period prior to the GFC increased at average annual rates 
well in excess of average real output growth in most G-7 nations. To put this growth into context, Campbell et.al. (2009) report that over the decade 1987-1996, real house prices in the US did not increase at all and that real house prices increased by less than $2 \%$ per year in real terms over the 1950-1996 period. Shiller (2005) argues that the behaviour of US house prices since 1997 has no precedent in the 20th century.

In Australia, Richards (2008) notes that since 1972 nationwide house prices have risen significantly faster than average household incomes, construction costs and average rents and that this constitutes evidence to support the view that housing might now be considered as a 'superior good', that is, a good to which consumers are allocating an increasing proportion of their incomes as incomes rise through time and where possession of such a good implies superiority of resources and is accompanied by prestige. Otto (2007) examined the relationship between house prices in Australian capital cities and a number of economic fundamentals. His study supports the view that there are significant relationships between house price changes and real economic variables and reports evidence of substantial differences in rates of price change between cities. Abelson et al. (2005) also examined house prices in Australia 1970-2003 and report that in the long run real house prices are determined significantly and positively by real disposable income and the consumer price index with other supply side economic fundamentals, such as unemployment and levels of the housing stock having a negative association with prices.

An associated view promoted by Beltratti and Morana (2009) and others is that the recent global house price surge may also be related to non-fundamental based mechanisms, such as, extravagant expectations of future price increases, spreading through contagion influences as suggested by Shiller (2007), or mispricing related to the combination of inflation and money illusion as argued by Brunnermeier and Julliard (2008). 
There is therefore considerable conjecture in the literature that actual house prices often do not reflect underlying fundamental determinants and we investigate this and related issues in this paper. As is the case with all asset prices, the fundamental price component is unobservable so that in order to make an empirical distinction between fundamental and non-fundamental components of an asset price, fundamentals must be modelled in terms of observable variables. We contribute to and extend the literature on house prices by doing this. In particular, our paper contributes to the literature in three ways.

First and most importantly, we use a dynamic present-value model and Australian house price data for the period 1984-2008 to decompose average Australian house prices into their fundamental and non-fundamental components. The present-value model we use is embedded in a vectorautoregressive (VAR) model used to generate expectations of future driving variables following earlier work by Black, Fraser and Groenewold (2003) and others on stock price data. The analysis by Richards (2008) for Australia suggests the importance of income as a driver of house prices while the recent paper by Hatzvi and Otto (2008) on the Sydney housing market emphasises the importance of time-variation in the discount rate. Our VAR model therefore involves three variables: house prices, income and a time-varying discount rate and is dynamic and forwardlooking. Naturally, the series derived for the fundamental component will be conditional on the assumptions underpinning the model, including the present-value assumption as well as the rational-expectations assumption which underlies expectations of future income. After computing the decomposition, we go on to analyse the relationship between the two components.

Our second contribution is to apply this procedure to house prices for the main regional housing markets, defined by the main state capital cities in order to assess the diversity and similarities between the behaviour of house prices in the different regions. We use the results of these regional decompositions to achieve our third aim which is to examine the extent to which shocks to non- 
fundamental components spill over from one region to another: do speculative or other forces which drive a wedge between actual and fundamental prices spill over from one region to another? To our knowledge, this is not an area which has been extensively researched in the housing literature with most of the inter-regional studies focusing on the spatial diffusion of price changes themselves rather than the transmission of non-fundamental components of house prices (see e.g. Clapp, Dolde and Tirtiroglu, 1995 and Dolde and Tirtiroglu, 1997 who have examined information diffusion processes in and between specific geographic market segments in US cities).

The key findings of the paper are as follows. Our results provide evidence of periods of sustained deviations of house prices from their fundamental values for the nation as a whole as well as for all state capitals, with the greatest deviations arising in the NSW market starting around 2000. The extent of the deviations varies considerably from state to state. In general, NSW also is relatively more susceptible to spillovers transmitted from other states while ACT and WA are least affected perhaps reflecting their economic and geographical isolation from the rest of the country. The significant variations observed between different regional markets also indicates that the relationship between house prices and interest rates is more complex than previously thought, given that in our period of analysis a standard monetary policy framework applied to all states. This result is consistent with the recent work of Campbell et al. (2009) who argue that changes in risk-free interest rates may not have done much to change housing valuations in US markets over the 19752007 period.

The remainder of this paper is organised as follows. In section 2 we present our theoretical and empirical framework. In section 3 we discuss data sources and provide some preliminary statistics. In sections 4 and 5 we discuss our empirical results with concluding remarks contained in the final section 6. 


\section{The Fundamental House Price Model}

The model for the fundamental component of house prices is based on the dividend-discount model which has been widely applied to the modelling of asset prices. In particular, we apply a linearized version of this model with a possibly time-varying discount rate originally due to Campbell and Shiller (C-S) and others in their analysis of stock prices; see, for example, Campbell and Shiller (1987, 1988a, 1988b) and Campbell and Ammer (1993).

The develop our theoretical model, we follow $\mathrm{C}-\mathrm{S}$ and begin by defining the return to house ownership, as the sum of the capital gain $P_{t+l} / P_{t}$ and the cash or amenities flow net of costs, $Q_{t}$ (which, for convenience, we call "rent"). Thus:

$1+\rho_{t}=\left(P_{t+1}+Q_{t}\right) / P_{t}$

where $\rho_{t}$ is the (possibly) time-varying stream of realized rates of return, $P_{t+l}$ is the real house price index one period ahead and $P_{t}$ is the real house price index at time $t .^{1}$

Taking logs and using lower case letters to represent the logs of their upper-case counterparts, we can write (1) as:

$r_{t}=\ln \left(1+\exp \left(q_{t}-p_{t+1}\right)\right)+p_{t+1}-p_{t}$

where $r$ denotes $\ln (1+\rho)$ and the term $(q-p)$ can be viewed as the economy-wide rent-house price ratio (the equivalent in the housing market of the dividend-price ratio for stocks).

The first term in (2) can be linearized about the sample mean using a first-order Taylor's expansion so that (2) can be aaproximated as:

$r_{t}=-\left(p_{t}-q_{t-1}\right)+\mu\left(p_{t+1}-q_{t}\right)+\Delta q_{t}+k$

\footnotetext{
${ }^{1}$ Campbell and Shiller (1988a, 1988b) both start directly from an equation of the form of (1). It is straightforward to show, though, that it can be derived directly from a standard net-present-value equation for the current value of the asset, $P_{t}$.
} 
where $k$ and $\mu$ are linearization constants:

$$
\begin{aligned}
& k=-\ln \mu-(1-\mu) \cdot \overline{(q-p)} \\
& \mu=1 /(1+\exp \overline{(q-p)})
\end{aligned}
$$

where $\overline{(q-p)}$ is the sample mean of $(q-p)$ about which the linearization was taken. Clearly, $0<\mu$ $<1$ and in practice is close to 1 .

Empirically, it is common that both $q$ and $p$ are $I(1)$ so that the variables are transformed to ensure stationarity. Denote by $\pi_{t}$ the $(\log )$ house price-rent ratio, $p_{t}-q_{t-1}$, and rewrite equation (3) as:

$\pi_{t}=k+\mu \pi_{t+1}+\Delta q_{t}-r_{t}$

After repeated substitution for $\pi_{t+1}, \pi_{t+2}, \ldots$ on the right-hand side of (4), we get:

$$
\pi_{t}=\frac{k\left(1-\mu^{i}\right)}{(1-\mu)}+\sum_{j=0}^{i-1} \mu^{j} \Delta q_{t+j}-\sum_{j=0}^{i-1} \mu^{j} r_{t+j}+\mu^{i} \pi_{t+i}
$$

Letting $\mathrm{i} \rightarrow \infty$ and assuming that the limit of the last term is 0 , results in the following alternative form of (5):

$$
\pi_{t}=\frac{k}{(1-\mu)}+\sum_{j=0}^{\infty} \mu^{j} \Delta q_{t+j}-\sum_{j=0}^{\infty} \mu^{j} r_{t+j}
$$

Hence, if $q_{t} \sim I(1)$ then $\Delta q_{t} \sim I(0)$ and, assuming that $r_{t} \sim I(0)$ (recall that it is the real return), then $\pi_{t}$ will be $I(0)$ and we have the model linearized and expressed in terms of stationary variables. Finally, taking conditional expectations of both sides:

$$
\pi_{t}=\frac{k}{(1-\mu)}+\sum_{j=0}^{\infty} \mu^{j} E_{t} \Delta q_{t+j}-\sum_{j=0}^{\infty} \mu^{j} E_{t} r_{t+j}
$$

where we interpret $r_{t+j}$ as investors' required return.

In order to generate our fundamental house price series, denoted $p^{*}$, we use (7) to generate a series for $\pi^{*}$, the house price-rent ratio implied by the model and use it to derive $p^{*_{t}}=\pi^{*}-q_{t-1}$. To do this we need, in turn, empirical counterparts to $q_{t}$ and the terms on the right-hand side of (7) involving expectations. 
While data for dividends for stocks, coupon payments for bonds and so on can readily be obtained for many financial assets, data for rental payments for houses, especially implicit rent for owneroccupiers which is included in our variable $q_{t}$, were impossible to obtain for our study so that we make the simplifying assumption that, in equilibrium, rent is what consumers of housing services are willing to pay and this, in turn, is linked to income. In particular, we assume that rent is a constant proportion of disposable income which allows us to relate the unobservable rental variable to observable disposable income in our empirical work.

Following this assumption, the first of the terms on the right-hand side of (7), the expectation of the growth of rent now becomes expected disposable income growth and to generate this we incorporate disposable income growth into a three-variable VAR model. For the second term on the right-hand side of (7), the expected return, we assume a time-varying required rate of return. The real required return can be decomposed into the real risk-free rate, $f$, and a real risk premium, $\theta$.

$$
E_{t} r_{t+j}=E_{t} f_{t+j}+\theta_{t}
$$

and we accommodate a time-varying required rate of return by allowing the risk-free rate to be time-varying while the risk premium is constant. ${ }^{2}$ The expression for $\pi_{t}$ in equation (7), then becomes:

$$
\pi_{t}=\frac{k-\theta}{(1-\mu)}+\sum_{j=0}^{\infty} \mu^{j} E_{t} \Delta q_{t+j}-\sum_{j=0}^{\infty} \mu^{j} E_{t} f_{t+j}
$$

\footnotetext{
${ }^{2}$ We also experimented with alternatives including a constant discount rate model - but the results indicated that in most cases, this model exhibited significantly greater deviations from actual prices than the time-varying discount rate model. Moreover, our presumption that the risk-free rate is time-varying is also supported by our empirical finding that the relevant coefficients are significantly different from zero in the model (see Table 3 below). Results based on alternative assumptions about the required return are available from the authors on request.
} 
Clearly, once we have removed the constant from this equation by using variables in terms of deviations from their means, this is formally equivalent to the case where the required return is time-varying in an unrestricted way.

The simpler case of a constant required rate of return allows us to simplify the model to a two variable VAR in $\mathbf{z}_{t}=\left(\pi_{t}, \Delta q_{t-1}\right)^{\prime}$. The equation analogous to equation (7) is then:

$\pi_{t}=\frac{k-r}{(1-\mu)}+\sum_{j=0}^{\infty} \mu^{j} E_{t} \Delta q_{t+j}$

In order to forecast both real income growth and the real risk-free rate we use a three-variable VAR in $\mathbf{z}_{t}=\left(\pi_{t}, \Delta q_{t-1}, f_{t}\right)^{\prime}$ which can be written in compact form as:

$\mathbf{z}_{t+1}=\mathbf{A} \mathbf{z}_{t}+\boldsymbol{\varepsilon}_{t+1}$

where $\mathbf{A}$ is a (3x3) matrix of coefficients and $\boldsymbol{\varepsilon}$ is a vector of error terms. We assume here a lag length of 1 for ease of exposition. If, in the empirical application, a longer lag length is required to capture the characteristics of the data, the companion form of the system can be used. Forecasts of the variables of interest $j$ periods ahead are achieved by multiplying $\mathbf{z}_{t}$ by the $j^{\text {th }}$ power of the matrix $\mathbf{A}$ :

$E_{t}\left(\mathbf{z}_{t+j}\right)=\mathbf{A}^{j} \mathbf{z}_{t}$

In this case and using the three-variable VAR for $\mathbf{z}_{t}$, the equation from which we compute the fundamental price-income ratio (and hence the fundamental house price) is:

$\pi_{t}^{*}=\frac{k-\theta}{1-\mu}+\left(\mathbf{e}_{2}^{\prime}-\mathbf{e}_{3}^{\prime}\right) \mathbf{A}(\mathbf{I}-\mu \mathbf{A})^{-1} \mathbf{z}_{t}$

where $\mathbf{e}_{2}^{\prime} \mathbf{A}^{j} \mathbf{z}_{t}=E_{t} \Delta q_{t+j}$ and $\mathbf{e}_{3}^{\prime} \mathbf{A}^{j} \mathbf{z}_{t}=E_{t} f_{t+j}$ where $\mathbf{e}_{2}^{\prime}$ and $\mathbf{e}_{3}^{\prime}$ are, respectively, the second and third unit vectors of appropriate dimension. Then we generate (the log of) fundamental house prices as:

$p_{t}^{*}=\pi_{t}^{*}+q_{t}$ 


\section{Data and Preliminary Statistics}

\subsection{Data}

To estimate the model and use it to generate fundamental house price series for the whole country as well as for the regions, we require suitable house price and income data for Australia as a whole as well as for the states. ${ }^{3}$ There is a voluminous literature on house price index estimation methods (see Prasad and Richards, 2008, and Hansen, 2009, for a recent Australian context) and some disagreement on the way in such indexes are best computed. A number of authors argue the merits of hedonic and repeat sale measures but our view is that these index methods are more suitable for the analysis of highly disaggregated housing markets. In any case, a consistent set of time series data required for VAR estimation for the country as a whole as well as for the states is not available in hedonic or repeat sales form. We, therefore, used the most extensive data set available - that for median house prices for the state capital cities available from the Real Estate Institute of Australia (REIA). We believe these to be consistent and reasonably robust, a view supported by Prasad and Richards (2008) who demonstrate empirically the robust time-series characteristics of stratified median house price indexes. We obtained quarterly data on aggregate Australian house prices and state capital house prices from the Real Estate Institute of Australia (REIA). This data comprises median house sale prices with some varying sample periods (discussed later). Given that we are interested in aggregate house price formation, we believe that aggregate city-wide median price indexes are suitable for our purposes. The data we used are quarterly and are available from the third quarter 1984 for all states except TAS and NT for which the series start in 1991(1) and 1994(1) respectively. Our sample finishes in 2008(2).

The quarterly macroeconomic data were obtained from the dXTime data base. For the nation as a whole we measured disposable income by Gross Disposable Income (seasonally adjusted) as well

\footnotetext{
${ }^{3}$ Australia has six states: New South Wales (NSW), Victoria (VIC), Queensland (QLD), South Australia (SA), Western Australia (WA) and Tasmania (TAS), as well as two territories: the Australian Capital Territory (ACT) and the Northern Territory (NT). We will use "states" to refer to both states and territories unless otherwise indicated.
} 
as by seasonally adjusted Domestic Final Demand (for reasons to be explained below); we deflated house price data by the CPI, all groups, weighted average eight capital cities. ${ }^{4}$ Disposable income, final demand and the CPI were all obtained from the ABS Time Series Plus section of dXTime. The risk-free rate was represented by the 90-day bank-accepted bill rate taken from the RBA section of dXTime. At the state level, disposable income data are not available nor, indeed, are data for output. The most comprehensive measure of economic activity available at the state level is for final demand so that for the states disposable income was proxied by State Final Demand (seasonally adjusted). House prices for each state were deflated by the CPI for each state capital city. State-level data for final demand and the CPI were also obtained from the ABS section of dXTime. Given effectively perfect capital mobility within Australia, the risk-free rate used for the nation as a whole was also used in the estimation of the state-level models.

The data are mismatched in several ways. First, we use house price data for capital cities but income data for the country as a whole or for each state as a whole. Given the limitations on available data, this problem is unavoidable..$^{5}$ It is likely to be less of a problem in Australia than in many other developed countries given the strong concentration of population in the capital cities of the Australian states. In 2006, the ratios of capital city private dwellings to state private dwellings

\footnotetext{
${ }^{4}$ Given we are calculating the return from holding residential property in terms of purchasing power over a general bundle of consumer goods (rather than measuring the price of housing relative to other goods) we deflate nominal house prices by CPI series which include a housing component. The real return to house ownership (investment) is then the nominal return less the change in the cost of living. Since investors also consume housing services the cost of this should be captured in the cost of living index.

${ }^{5}$ The Australian Bureau of Statistics state when referring to the collection of house price data: "For the immediate future, geographic scope continues to be restricted to the eight capital cities ...." and "The aim of providing rest of state indexes remains a longer term objective."

http://www.abs.gov.au/AUSSTATS/abs@.nsf/Latestproducts/6464.0Main\%20Features42009?opendocument\&tabname $=\underline{\text { Summary } \& \text { prodno }=6464.0 \& \text { issue }=2009 \& \text { num }=\& \text { view }=}$
}

Thus it is recognised that capital city house prices dominate. 
were: Canberra, 100\%; Sydney, 60\%; Darwin, 59\%; Brisbane, 43\%; Adelaide, 71\%; Hobart,40\%; Melbourne 70\%; Perth, $72 \% .{ }^{6}$ Moreover, for the purposes of our model, rates of change in income and not the levels of income are the important variable so that differences in level occasioned by differences in coverage will not affect the analysis (although it is possible, of course, that rates of change will differ between the capital city and the rest of the state).

The second mismatch is between state disposable income and final demand since the model requires the former but the data dictate the use of the latter. To gain some insight into the possible effect on our results of using final demand rather than disposable income for the states, we also experimented with the use of final demand at the national level for which we have disposable income so that a direct comparison can be made. Our results indicate that, at least at the national level, the nature of our results do not change with this switch.

State real final demand data are transformed before they are used in the model to generate the fundamental price series. This is done to ensure that the log of the ratio of real house prices to final demand, $\pi_{t}$, has the same dimension as the log of the real house price-rent ratio (or the pricedividend ratio in the case of stock prices). The transformation is achieved by first calculating: $S=\left[(1+R R) P_{t-1}-P_{t}\right] / Y_{t-1}$ where $R R$ is the real required return, $P_{t}$ is the value of the house price series at time $t$ and $Y_{t-1}$ is the (lagged) real final demand proxy for real disposable income. The value of $R R$ is calculated as the sample average quarterly real house price return inclusive of rental income. ${ }^{7}$ The log of the product of the variable $S$ and real final demand gives a time series of final demand which has the same dimension as that of rents and is denoted $q_{t}$.

\footnotetext{
${ }^{6}$ See http://www.abs.gov.au/websitedbs/d3310114.nsf/Home/census

${ }^{7}$ Net quarterly rental income was estimated from gross rental data sourced from REIA and added to the time series of house price returns to provide a time series of returns which included an allowance for net rental yield. The net rental yield was estimated to be $70 \%$ of gross rents.
} 


\subsection{Preliminary Statistics}

Given that our empirical work below, and its interpretation, assumes that state level final demand figures are a good proxy for state level disposable income figures, we display in Figures 1 and 2 graphs of (aggregate) National Domestic Final Demand (DFD) and (aggregate) National Disposable Income (DISPINC) in both levels and growth rates.

\section{[Figures 1 and 2 about here]}

The very high correlation between the levels of the two variables $(0.9995)$ reflects the very similar trending behaviour of the two series at the national level, while the correlation of 0.486 between growth rates also suggests that changes in these variables have a close association. While the gap between the levels of the two variables tends to widen in the latter part of the sample, particularly since 2002, final demand in the economy is consistently at a higher level than disposable income, reflecting, at least in part, the funding of final demand by debt. ${ }^{8}$ Overall however, final demand would appear to follow a very similar time path to disposable income and we are therefore confident that state final demand is a suitable proxy variable for disposable income at the state level.

Tables 1a - 1i report summary statistics for key variables of interest for all Australia and each of the Australian states and territories. Also reported in each table are the long-lag autocorrelation coefficients and significance statistics (Q-statistics and probabilities) for the log house price-income ratio, $\pi_{t}$. These long-lag autocorrelation coefficients are reported as an alternative method of describing the mean-reverting properties of the data.

\section{[Tables 1a - 1i about here]}

While aggregate average real (inflation-adjusted) housing returns were $1 \%$ per quarter, with an associated standard deviation of $3.2 \%$, the highest average real return over the 24 years since 1984

\footnotetext{
${ }^{8}$ The correlation between the rates of change on these two variables increases if year-on-year changes are used rather than quarterly changes suggesting that much of the discrepancy in change between the two variables is very short term.
} 
was achieved by WA at $1.3 \%$ per quarter. This return is associated with ex-post risk (as measured by standard deviation) of $4.5 \%$ with only QLD and SA having lower risk over the same period but with lower associated quarterly real returns of $1.1 \%$ and $0.8 \%$ respectively. NSW and VIC report the same growth rate of house prices at $1 \%$ per quarter - the latter having relatively more variability. Over the same sample period ACT exhibited the least attractive return- risk combination with a $0.8 \%$ quarterly real return but associated with ex post risk of $4.5 \%$. Over shorter sample periods, the NT and TAS returned an average of $1.2 \%$ and $1.3 \%$ per quarter, respectively with the latter exhibiting highest quarterly ex-post risk of $5.5 \%$.

Table 1a also supports the use of final demand as a proxy for disposable income: sample means and variances are the same as are the stationarity (Unit Root tests) and normality (J-B statistics) properties of the data. Over common sample periods, (scaled) real final demand growth (the real disposable income proxy), $\Delta q_{t}$, was highest for QLD at $1.2 \%$ per quarter, closely following by WA at $1.1 \%$ per quarter and $\mathrm{ACT}$ at $1 \%$ per quarter. Of these three states, QLD's demand growth rates had the lowest sample standard deviation at $1.7 \%$ per quarter. Such growth rates compare favourably with those for VIC at $0.7 \%$, NSW at $0.6 \%$, and SA at $0.5 \%$, over the same period. NSW exhibited the least variability in growth rates with a quarterly standard deviation of $1.4 \%$. Over the shorter sample periods, NT and TAS had average quarterly final demand growth rates of $1.3 \%$ and $0.6 \%$ respectively with the former displaying the relatively high quarterly standard deviation of 4.5\%. When all states were compared over the common period from $2001 \mathrm{Q} 1$ to the end of the sample, the difference between NSW per quarter income growth rates and other states was more pronounced with NSW rates slightly lower than for the full sample at $0.55 \%$, while other states income increased: WA and NT at 1.5\%; ACT and QLD at 1.4\%; TAS at 1.2\%; VIC at $0.9 \%$; and SA at $0.7 \%$. 
Full sample means of the log house price - income ratios $\left(\pi_{t}\right)$ imply yields of between $3.4 \%$ (NSW) and $4.56 \%$ (NT) per annum with all Australia averaging $3.58 \%$ per year. ${ }^{9}$ Reliable rental yield series for Australian cities are notoriously difficult to estimate; however, anecdotal evidence indicates the broad yield levels revealed by this calculation are indicative of the major housing markets we analysed. Over the common sample period, real risk-free returns $\left(f_{t}\right)$, averaging $1.1 \%$ per quarter, and their associated variability, are very similar across states, indicating state inflation rates were also very similar over the period. The NT and TAS report quarterly average real riskfree returns of $0.8 \%$ and $0.9 \%$, associated with standard deviations of $0.63 \%$ and $0.71 \%$ respectively. With some exceptions (NSW, TAS and WA) house price returns in Australia have tended not to be able to reject the normality hypothesis (J-B) at the $10 \%$ level of significance.

We also report stationary tests. With the exception of the log price-income ratio $\left(\pi_{t}\right)$, the returns and growth rates are stationary as reflected in the ADF statistics. The levels of the log house prices and income series were non-stationary (not reported) indicating these series can be characterised as I(1) processes. However, graphs of the data (not reported) show long swings in the $\pi_{t}$ series, indicating mean reversion in the long term but insufficient data for this to be apparent in the test results with limited lags. Similar time series characteristics have also been reported using dividend-price ratios (see e.g. Black, Fraser and Groenewold, 2003). Hence at the end of Tables 1a-1i we also report autocorrelation coefficients for various lag lengths, the first of these being the lag at which predominately negative autocorrelation for each of the series begins. While all series report significant mean reversion, thus stationary characteristics, at long lags, the signs on the coefficient estimates indicate that VIC and NSW house price-income yields, with at least 25 quarters before mean reversion begins, have tended to exhibit the deepest cycles with QLD and the NT exhibiting the relatively shallow cycles with turning points of 13 and 14 quarters respectively. We therefore

\footnotetext{
${ }^{9}$ Note that $\pi_{\mathrm{t}}$ is the negative $\log$ of the rental-price ratio or the yield so that, taking the all Australia case, for example, the yield is $e^{-4.717}=0.894 \%$ per quarter $=3.58 \%$ per year.
} 
proceed on the basis of the evidence of mean reversion at long lags on the assumption that in all cases, $\pi_{\mathrm{t}}$, is stationary.

As an additional descriptor of the long-run relationship between real house prices and real final demand (at national and state levels of activity), we also report in Table 2, results from Johansen tests for the cointegration of these two series. The test statistics convincingly reject the null of nocointegration between house prices and final demand at both state and national levels: hence while these two variables of interest may deviate in the short-run, they have an inherent tendency to move together over the long-run. ${ }^{10}$

\section{Empirical Results}

\subsection{VAR Models}

Table 3 reports the VAR coefficient estimates and specification tests for Australia as a whole and each of the states. To ensure residual white noise all Australia and NSW required 3 lags of the variables in the RHS of the VAR while the remainder required 2 lags. Own lags on the priceincome ratio in particular are highly significant in two cases (QLD, WA), their value being greater than unity. In both cases however, the sum of the lagged coefficients is less than one - a feature which is relevant to stationarity. Own lags on income growth are less important for ACT, NT, TAS and WA. As expected, the relationship between the discount rate and the price-income ratio is a negative one while, the discount rate - income growth relationship varies depending on the lag. The results vindicate our use of a time-varying discount rate in our model since the risk-free rate is strongly autocorrelated and so not constant as well as being significantly related to many of the variables in the model. Notably, the discount rate is (with the exception of NT and TAS)

\footnotetext{
${ }^{10}$ Note that the stationarity of $\pi_{t}$ is a test of the cointegration of $p_{t}$ and $q_{t}$ with a cointegrating vector of $(1,-1)$ while the Johansen test does not impose any restriction on the nature of the cointegrating vector. Hence rejection of stationarity of $\pi_{t}$ while $p_{t}$ and $q_{t}$ are cointegrated suggests that the cointegrating vector is other than $(1,-1)$.
} 
significantly different from zero in both house price-income ratio equations $\left(\pi_{t}\right)$ and income growth equations $\left(\Delta q_{t-1}\right)$. The Q statistics suggest the models are correctly specified with respect to the absence of residual autocorrelation.

The VAR coefficients also allow us to determine whether growth of income or the discount rate (as proxied by the risk-free rate) have been more important in determining the time series behaviour of the house price income ratio. As far as all Australia is concerned, the discount rate at the second lag has significant predictive power for the price-income ratio, while income growth is consistently insignificant. With the exception of ACT, NT and TAS, the discount rate also has predictive power at either one or two lags for each of the states and only for TAS and WA do we find predictive power for lagged income growth with respect to the price-income ratio. Further, for ACT, NSW, SA and TAS, the price-income ratio has significant predictive power for the discount rate; hence any ability of the price-income ratio to predict housing returns is due to a close relationship between the price-income ratio and the discount rate. For all Australia, NSW, QLD SA and VIC, the priceincome ratio also predicts income growth.

\subsection{Actual v. Fundamental House Prices}

We now report results which throw light on one of the main objectives of the paper, namely, the extent to which actual and fundamental prices have deviated over time. Figure 3 displays graphs of the time series of (nominal) actual and fundamental house prices (as warranted by the model detailed above) for all Australia and the eight states. In Figure 3, the first two graphs show the relevant prices for all Australia, the first based on the domestic final demand (DFD) proxy for disposable income and the second using disposable income itself. A comparison of these two graphs provide clear evidence that, at least at the national level, the use of the final demand proxy has little effect on the time path of fundamental prices generated by our model. Both graphs show that there are persistent deviations between actual and fundamental prices over the sample, 
particularly post-2003. The same is true in general for the individual state results pictured in the remaining graphs, with the deviations largest for the largest of the states, NSW. While there are considerable deviations of actual from fundamental, it is useful to view this in the context if earlier applications of the model to stock prices. Thus, for example, Black Fraser and Groenewold (2003) apply it to US stock prices where much larger deviations of actual from fundamental were evident, a surprising comparison perhaps, in that stock markets are generally considered more efficient than housing markets so that we would expect smaller deviations of stock prices from their fundamentals. Naturally, this is conditional on the model being an adequate measure of fundamentals, a matter to which we return below.

\section{[ Figure 2 about here]}

It is interesting to ask whether the deviation of house prices from their fundamental levels is significant in a statistical sense. To assess this we can use a Wald test to test the hypothesis that $\pi_{t}$ $=\pi_{t}^{*}$ for all $t$. Since $\pi_{t}=\mathbf{e}_{1}^{\prime} \mathbf{z}_{t}$ where $\mathbf{e}_{1}^{\prime}$ is the first unit vector, we can write (12), after transforming the variables to deviations from their means to remove the constant term, as:

$$
\mathbf{e}_{1}^{\prime} \mathbf{z}_{t}=\left(\mathbf{e}_{2}^{\prime}-\mathbf{e}_{3}^{\prime}\right) A(I-\mu A)^{-1} \mathbf{z}_{t}
$$

For this to hold for all $t$, requires:

$$
\mathbf{e}_{1}^{\prime}=\left(\mathbf{e}_{2}^{\prime}-\mathbf{e}_{3}^{\prime}\right) A(I-\mu A)^{-1}
$$

which constitutes a set of non-linear restrictions on the coefficients of the VAR. They can be tested using the "delta method" (see Campbell et al. 1997, p.540), which is based on writing equation (14) as

$\pi_{t}^{*}=\mathbf{k}^{\prime} \mathbf{z}_{\mathbf{t}}$

where $\mathbf{k}^{\prime}=\left(k_{1}, k_{2}, k_{3}\right)=\left(\mathbf{e}_{\mathbf{2}}^{\prime}-\mathbf{e}_{\mathbf{3}}^{\prime}\right) \mathbf{A}(\mathbf{I}-\mu \mathbf{A})^{-1}$ so that a test of $\pi_{t}=\pi_{t}^{*}$ is equivalent to a test of $\mathbf{k}=\mathbf{e}_{1}$ which can be tested using the Wald statistic:

Wald $=\left(\mathbf{k}-\mathbf{e}_{1}\right)^{\prime}\left[(\partial \mathbf{k} / \partial \mathbf{A}) \boldsymbol{\Omega}(\partial \mathbf{k} / \partial \mathbf{A})^{\prime}\right]^{-1}\left(\mathbf{k}-\mathbf{e}_{1}\right)$ 
where $\boldsymbol{\Omega}$ is the variance-covariance matrix of the VAR coefficients and the matrices of the partial derivatives of $\mathbf{k}$ with respect to the elements of $\mathbf{A}$ are evaluated at the estimated value of $\mathbf{A}$ and can be computed numerically. Under the hypothesis that the model is true, the Wald statistic is asymptotically $\chi^{2}$-distributed with $3 p$ degrees of freedom (number of equations in the VAR multiplied by the number of lags, $p$ ).

An alternative form of the restrictions is obtained by post-multiplying both sides of (15) by (I- $\mu \mathbf{A})$ which provides a linear form of restrictions:

$\mathbf{e}_{1}^{\prime}(\mathbf{I}-\mu \mathbf{A})=\left(\mathbf{e}_{2}^{\prime}-\mathbf{e}_{3}^{\prime}\right) \mathbf{A}$

or

$\mathbf{e}_{1}^{\prime}(\mathbf{I}-\mu \mathrm{A})-\left(\mathbf{e}_{2}^{\prime}-\mathbf{e}_{3}^{\prime}\right) \mathbf{A}=0$

which is linear in the elements of $\mathbf{A}$. The linear restrictions can be tested with a standard Wald test which is asymptotically $\chi^{2}$-distributed with, $3 p$ degrees of freedom where $p$ denotes the number of lags in the system.

The results of the Wald tests are reported in the last two columns in each of the panels in Table 3. The results show that despite the apparent persistent deviations of the actual from fundamental prices, the null cannot be rejected in all cases. In particular, for all Australia, NSW and VIC, the linear and non-linear Wald tests both suggest we are able to reject the null that $\pi_{t}=\pi_{t} *$. For ACT and NT, only the non-linear Wald test is able to reject the null that $\pi_{t}=\pi_{t}^{*}$ while for QLD and TAS, both tests are unable to reject the null hypothesis. For SA and WA, the linear Wald rejects the restrictions imposed while only at the $2 \%$ level can the non-linear Wald test fail to reject the null that the actual and theoretical series are the same. 
Table 4 provides additional statistical information relevant to the comparison of the actual and fundamental prices. From Table 4 the small average negative values for $\left(p_{t}-p_{t}^{*}\right) / p_{t}$ in the full sample period in Australia and all States indicate that in general actual house prices have been slightly below our estimates of fundamental house prices. As confirmed by an examination of the graphs in figure 3 , it is important to note the difference explained by temporal variation in the later part of the sample period. In Table 4 we also report our estimate for the final sample period confirming that in 2008:Q2 actual house prices in most states were significantly above our forecast of fundamental house prices.

\section{[ Table 4 about here]}

Considering the state level graphs, the greatest deviations from fundamental values arise in the NSW market where we can see bubble-type behaviour in terms of sustained deviations from fundamental value which in turn has led to a convincing rejection of both the linear and non-linear Wald tests. The most recent peak occurred in 2004 after a sustained period of price increase, relative to those warranted by income and the discount rate, starting around 2000. Prior to these periods, our estimates suggest that prices were below their fundamental value for around 10 years. From Table 4 it can be seen that NSW displays the highest variability between actual and fundamental house prices over the full sample period as measured by standard deviation and root mean square deviation (RMSD).

In ACT, NT and VIC markets it is evident that there have also been periods of sustained deviation from fundamental values, again supported by the relevant non-linear Wald tests. Of these three states, only NT has been overvalued in recent years (since late 2005) while the others display values close to the fundamental over this period. Interestingly, since 2001, VIC house prices have been mostly below their fundamental value. QLD and WA, while experiencing some short-term overvaluation in the very recent past, have generally kept close to their fundamental values. Both SA and TAS however have, since 2003, exhibited an (ongoing) increase in the gap between actual 
and fundamental prices, although over the period up to 2003, both price series have tracked each other quite well.

As indicated by the graphs, all states experienced significant house price inflation from around 2003 but there are clear indications that this increase differed not only in magnitude across states but also in terms of whether or not such increases were warranted by expectations of future income as well as the individual state's ability to sustain the price increases. The observation of persistent deviations between actual and fundamental prices, particularly in recent years, begs the question as to the cause of such deviations. While it is impossible to answer this question without further (preferably structural) modelling, it is possible to make some headway in our understanding of the behaviour of house prices and their interactions with income.

We can therefore conjecture that a reason for the sensitivity of NSW with respect to deviations of actual prices from the fundamental price (as defined by our model) may be a consequence of it experiencing a relatively low net amenities flow, as indicated by the relatively low real income growth rate, $\Delta q_{t}$ over this period reported above. Hence, a change in price will have a relatively large impact on the total returns from housing as measured by the sum of capital gain and amenities flow, the latter maintained as being proportional to income. At least to some extent, this would imply that NSW may be relatively less insulated from booms and busts than other states. Further, given that estimated fundamental prices are generated from a combination of the dynamic discounted present value model and the forecasting assumption of rational expectations, the observed deviations may be due to deficient characterization of house price drivers such as, timevarying supply constraints and transaction costs or/and, attributing too much expectation sophistication to agents operating in these markets who, in practice, may base their activity on extravagant expectations of future price changes or/and future income growth (see e.g. Fraser et al. (2008), which in turn has resulted in price bubbles. 


\section{Spillover Effects}

In this section address our third aim which is to examine the spillover from one region to another of the non-fundamental component of house prices in order to investigate whether what might be called "speculative" activity in one market spills over into others. We do this by analysing the interrelationships between the states' non-fundamental price components within a VAR/VECM (vector error correction model) framework.

We proceed by modelling the non-fundamental components of actual house prices as measured by deviations of actual house prices from fundamental house prices. We first test for the stationarity of the deviations from fundamentals and, if non-stationarity is found, also for cointegration before deciding on whether to use a VAR model or a VECM. We limit our analysis to the states for which we have data for the full sample period, 1984Q3-2008Q2. This necessitates excluding TAS and the NT; including these requires restricting the sample period to start in 1991 and preliminary experimentation with this shorter sample period often produced results which were very sensitive to model specification. Given the relatively small size of these two states, this is not likely to result in a serious limitation of the applicability of our results.

Consider first the question of the stationarity of the non-fundamental components. The results of the application of the ADF test using an intercept, no trend and lags chosen by standard criteria, are reported in Table 5 .

\section{[Table 5 about here]}

All variables are I(1) with WA requiring the highest number of lags (4 lags according to AIC lag length criterion). Hence we proceed to test for cointegration. The cointegration tests were based on a VECM with a constant but no trend in the cointegrating vector and a constant in the VAR equations. The lag length was set at 2 , following lag exclusion and autocorrelation tests. Within this framework, the Johansen test, reported in Table 6 , showed a single cointegrating vector whether 
the trace or the eigenvalue form of the test was used. We conclude that the variables are cointegrated and analyse them within a VECM.

\section{[Table 6 about here]}

The main tool for the analysis of spillovers IRF which traces the effect on each of the variables in the model of a shock to the error of one of the equations. There are various ways in which the errors can be shocked, depending on the way in which the historical correlations are taken into account. The most common procedure is based on an orthogonalization of the errors using a Choleski decomposition of the error covariance matrix to compute independent components of the equation errors and it is these independent components which are shocked. While the method accounts for the historical correlations, it does so in an artificial way which makes the results dependent on the essentially arbitrary ordering of the variables in the model. An alternative is to ignore the historical error correlations and shock the model errors as though they were independent. We use this second approach on the basis that we want to analyse the spillovers from shocks originating in only one region rather than shocks which reflect the way in which they have behaved on average over the sample. We impose unit shocks which represent a $1 \%$ increase given that prices are in logs.

In the interpretation of the spillovers, we focus on the longer-term effects - the effects in period 1 are completely determined by our modelling assumption since the shock size is set to 1 and the first-period effects are felt only in the state which is being shocked. Moreover, the effects over the first 5 periods are quite sensitive to assumptions about lags but the longer-run effects are not. The IRFs are reported in Figure 4 with the long-run impacts summarised in Table 7.

[Figure 4 about here]

[Table 7 about here] 
There are clearly widespread spillovers but they vary considerably in magnitude from one region to another. For all states except NSW, the state's own shock has the largest positive effect in the long term. Surprisingly, NSW receives the largest spillovers - given that it is the largest state in economic terms, we might have expected it to be the source, not the recipient, of the largest spillovers. In particular, NSW receives large positive spillovers from SA and large negative ones from WA. Its spillovers to other states is relatively modest, particularly to the contiguous VIC and SA. By way of contrast, VIC, the second-largest state, is less affected by spillovers from other states and itself affects almost all other states negatively. At the other end of the spectrum, both WA and ACT dance largely to their own tune. Neither of these results are unexpected - Canberra is in many ways unconnected from the rest of the country and this appears to apply to the housing market too and WA with its great distance from the other population centres is probably not a serious substitute for the other state capitals as a place to live.

\section{Summary and Conclusions}

Using Australian capital city data from 1984Q3-2008Q2, this paper utilizes a dynamic present value model within a VAR framework to construct fundamental time series of house prices depicting what aggregate house prices should be given expectations of future real disposable income and future discount rates - the 'fundamental price' and continues by comparing capital city fundamental prices with actual prices. The extent to which deviations of actual from fundamental prices spillover from state to state, as well as their long-term impacts is also investigated.

Our results provide evidence of periods of sustained deviations of house prices from values warranted by discounted future income for all state capitals with the greatest deviations arising in the NSW market and starting around 2000. NT has been overvalued in recent years (since late 2005) while ACT and VIC display values close to the fundamental over this period. Interestingly, since 2001, VIC house prices have been mostly below their fundamental value. QLD and, in 
particular, WA, while experiencing some short-term overvaluation in the very recent past, have generally kept close to their fundamental values with the results suggesting WA house prices are set in a relatively efficient marketplace. Both SA and TAS however have, since 2003, exhibited an (ongoing) increase in the gap between actual and fundamental prices, although over the period up to 2003, both price series have tracked each other quite well.

In general NSW is also relatively more susceptible to spillovers transmitted from other states while ACT and WA are least affected. Notably however, a shock to the non-fundamental component of WA transmits, on average, a shock of equal magnitude, but negative, to that of NSW, while a shock to SA has a positive impact of equal magnitude on the non-fundamental component of house prices in NSW. Only shocks to QLD and ACT have an impact on WA and these are very limited. The remaining shocks impacting between states are modest. It would appear that, with the exception of NSW, capital city housing markets are relatively segmented with respect to the transmission of nonfundamental shocks. Fruitful areas of future research may be channelled towards formal testing of hypotheses regarded the reasons for the spillover anomalies highlighted above.

Overall, the results reported above suggest that the response of capital city housing markets to uniform economic stimuli will have different impacts regarding the relationship between actual house prices and the fundamental price. Further, given the frequent calls for a global response to the GFC it is important that policymakers take into account the uniqueness of the Australian and state housing market characteristics and thus enlighten Australia-specific policy decisions. We hesitate to draw too much by way of practical policy implications of our model. While it is tempting to speculate about the causes of the diversity we uncover it is impossible to be definitive given the theoretical structure of our model. We do suggest however that NSW may be relatively less insulated from house price hikes than other states and that price dynamics as well as overreactions to fundamentals may be driving such deviations. We have noted a number of caveats along the way, 
particularly the weaknesses of the data (especially at the state level) and the simplicity of our model (a dividend-discount model plus rational expectations) and much work remains to be done, especially by way of structural modelling, before we have a thorough understanding of the price dynamics of Australian national and regional house prices and their impact on the real economy. While we place this on our agenda for future research we nevertheless feel that the work reported here can make a useful contribution to our understanding of the behaviour of house prices with respect to their interactions with income within and between regions of the Australian housing market. 


\section{References}

Australian Bureau of Statistics. 2009. House price indexes: eight capital cities, Sepember. Publication: 6416.0. http://www.abs.gov.au/ausstats/abs@.nsf/mf/6416.0

Abelson, P., Joyeaux, R., Milunovich, G., Chung D. 2005. Explaining house prices in Australia: 1970-2003. The Economic Record, 81, pp. 96-103.

Beltratti, A., Morana, C. 2009. International house prices and macroeconomic fluctuations. Journal of Banking and Finance, 34 (3), pp. 533-545.

Black, A., Fraser, P., Groenewold, N. 2003. US stock prices and fundamentals. International Review of Economics and Finance, 188, pp. 1-23.

Brunnermeier, M.K., Julliard, C. 2008. Money illusion and housing frenzies. The Review of Financial Studies, 21, pp. 135-180.

Campbell, J. Y., Ammer, J. 1993. What moves the stock and bond markets? A variance decomposition for long-term asset returns. Journal of Finance, 48 (1), pp. 3-37.

Campbell, J. Y., Shiller, R. J. 1987. Cointegration and tests of present value models, Journal of Political Economy, 95, pp. 1062-1088.

Campbell, J.Y., and R.J. Shiller, 1988a. Stock prices, earnings and expected dividends, Journal of Finance 43, pp. 661-676.

Campbell, J.Y., and Shiller, R. J. 1988b. The dividend-price ratio and expectations of future dividends and discount factor, Review of Financial Studies, 1, pp. 195-228.

Campbell, J. Y., Lo A.W., MacKinlay, C. 1997. The econometrics of financial markets, Princeton: Princeton University Press.

Campbell, S.D., Davis, M.A., Gallin, J., Martin, R.F. 2009. What moves housing markets: A variance decomposition of the rent price ratio. Journal of Urban Economics, 66 (2) p.90.

Clapp, J.M., Dolde, W., Tirtiroglu, D. 1995. Imperfect information and investor inferences from housing price dynamics. Real Estate Economics, 1995, 23 (3), pp. 239-269.

Dolde, W., and Tirtiroglu, D. 1997. Temporal and spatial information diffusion in real estate price changes and variances. Real Estate Economics, 25 (4), pp. 539-565.

Fraser, P., Hoesli, M. and McAlevey, L. (2008), House prices and bubbles in New Zealand. Journal of Real Estate Finance and Economics, 37, pp. 71-91.

Hansen, J. (2009). 'Australian house prices: A comparison of hedonic and repeat-sales measures', The Economic Record, 85 (269), pp. 132-145.

Hatzvi, E. and Otto, G. (2008). Prices, Rents and rational speculative bubbles in the Sydney housing market. The Economic record, 84, pp. 405-420.

Murdoch, S. 2009. RBA warns of housing bubble risk, The Australian Newspaper, Business, July 28, 2009. 
From: http://www.news.com.au/business/story/0,27753,25847312-462,00.html

Otto, G. 2007. The growth of house prices in Australian capital cities: What do economic fundamentals explain? The Australian Economic Review, September, p. 403.

Prasad, N. and Richards, A. 2008. Improving median house price indexes through stratification. Journal of Real Estate Research, 30, pp. 45-72.

Richards, A. 2008. Some observations on the cost of housing in Australia, Address to 2008 Economic and Social Outlook Conference by Anthony Richards, Head of Economic Analysis Department, Reserve Bank of Australia.

From: http://www.rba.gov.au/Speeches/2008/sp_so_270308.html\#t1

Shiller, R. 2005. Irrational Exuberance, second ed. Princeton University Press, Princeton, NJ.

Shiller, R.J. 2007. Understanding recent trends in house prices and home ownership. NBER Working Paper Series, No. 13553.

Standard \& Poors. 2009. Nationally, home prices began 2009 with record declines according to the S\&P/Case-Shiller home price indices, press release May 26, 2009.

From:

http://www2.standardandpoors.com/portal/site/sp/en/us/page.topic/indices_csmahp/2,3,4,0,0,0,0,0,0 $, 0,0,0,0,0,0 . \mathrm{html}$ 
Figure 1 Levels of Domestic Final Demand and Disposable Income

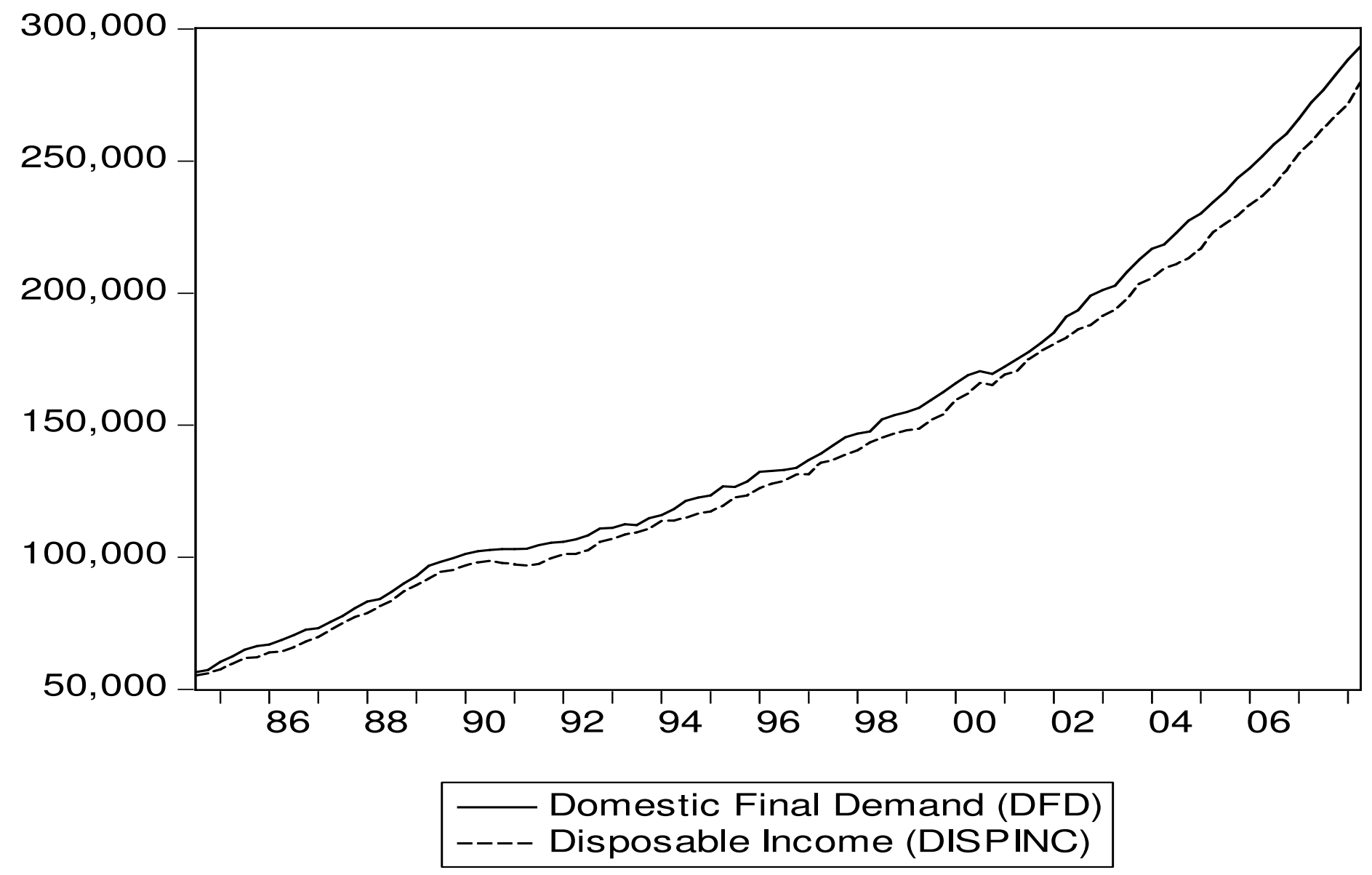


Figure 2. Growth Rates of Domestic Final Demand and Disposable Income

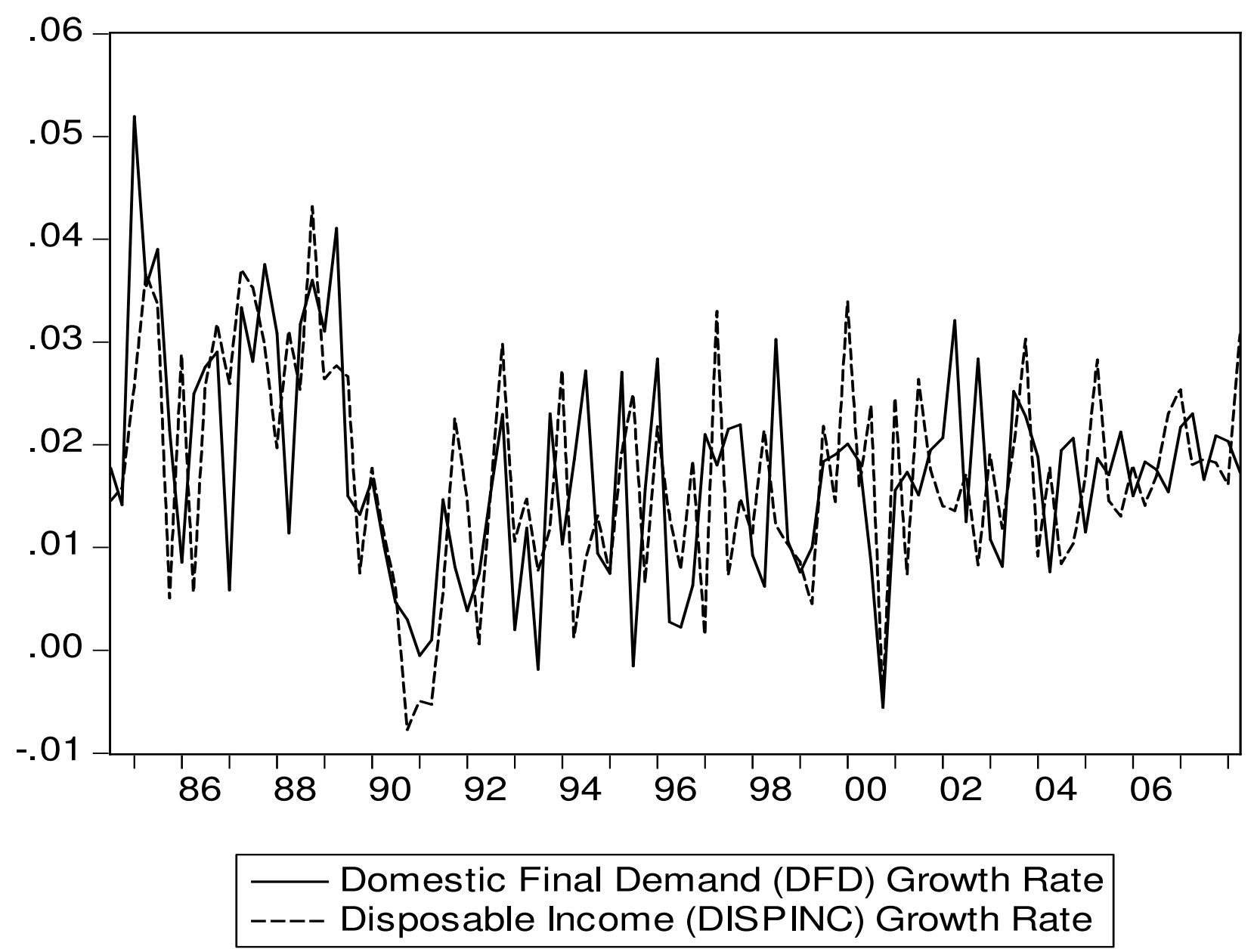




\section{Figure 3. Actual and Fundamental House Prices}
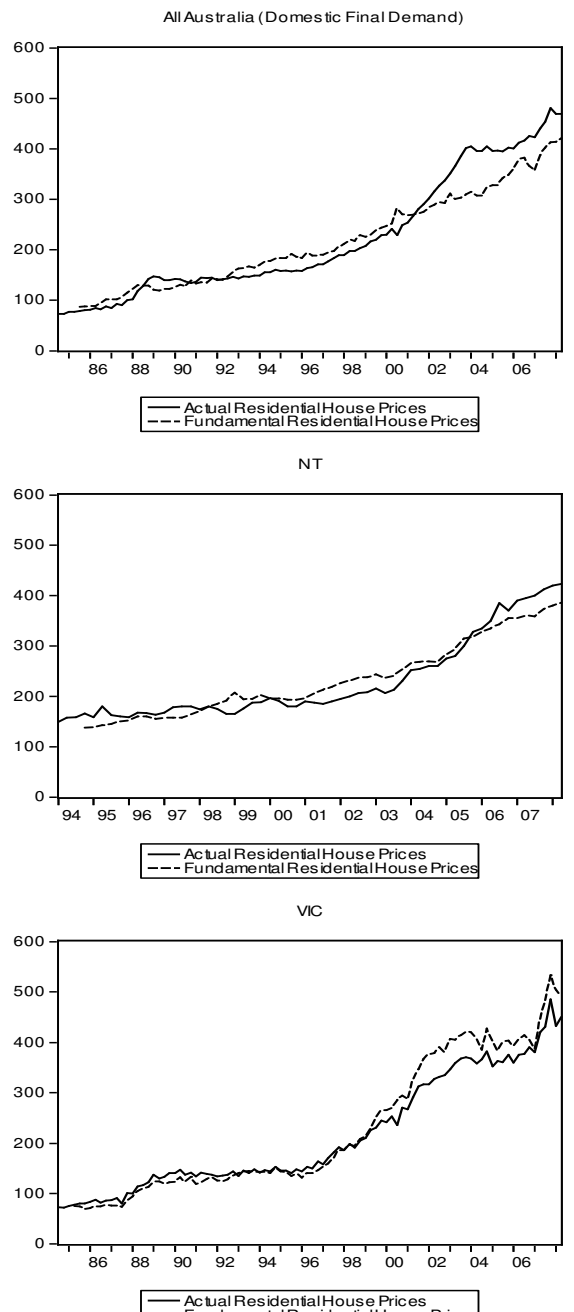

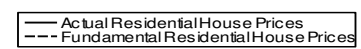

All Australia (Dispos able Income)
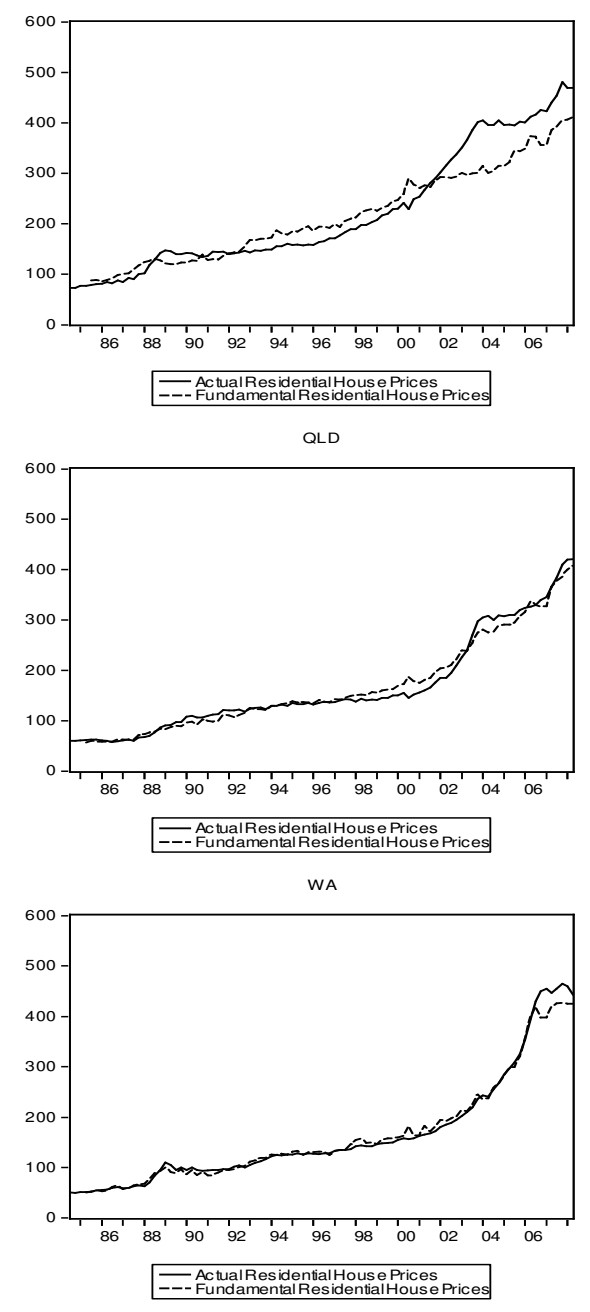
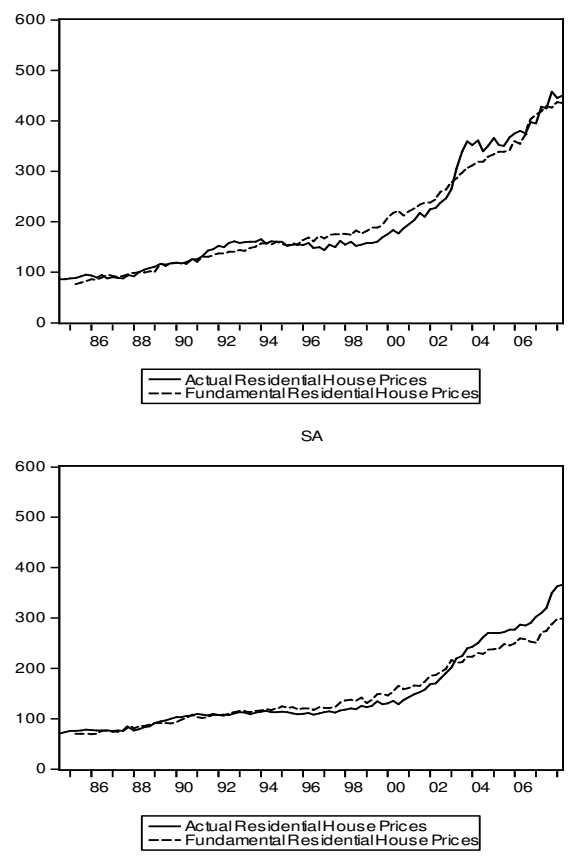

NSW
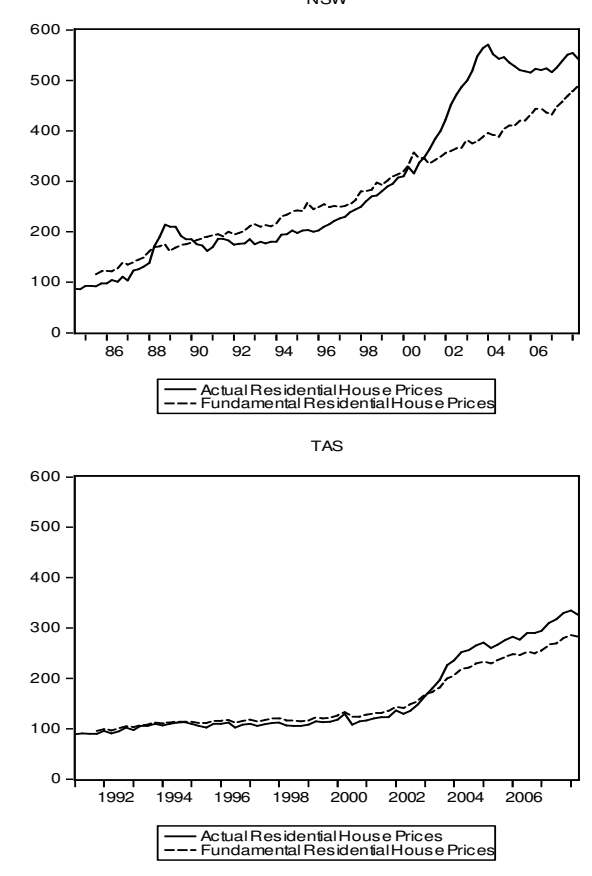


\section{Figure 4. Spillovers in Non-Fundamental Components of House Prices (Black \& White version on next page)}

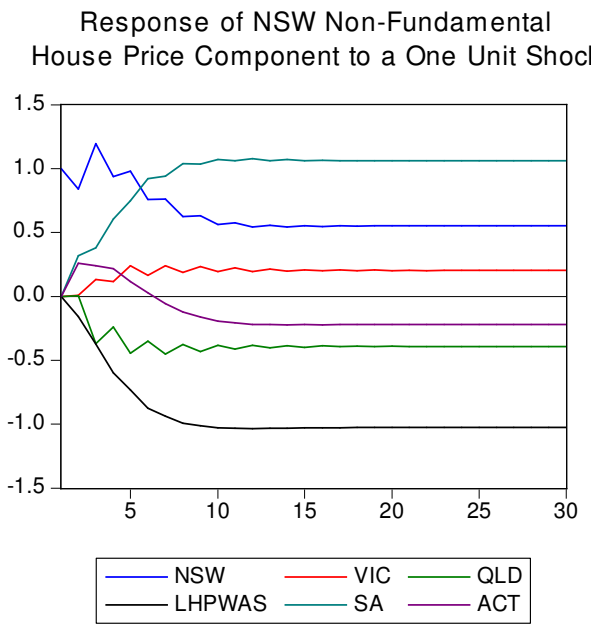

Response of QLD Non-Fundamental House Price Component to a One Unit Shock

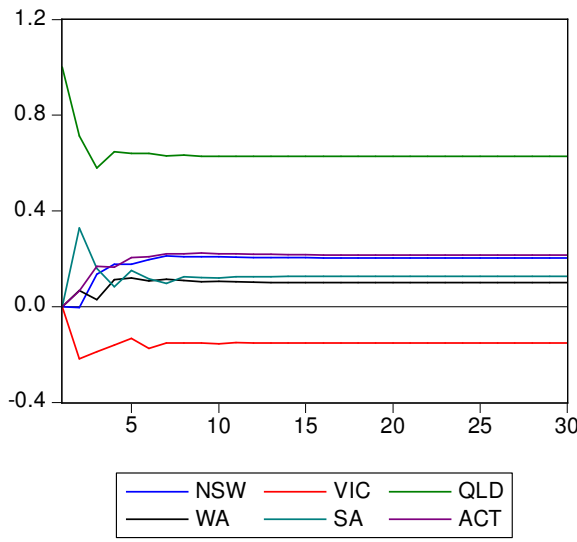

Response of SA Non-Fundamental House Price Component to a One Unit Shock

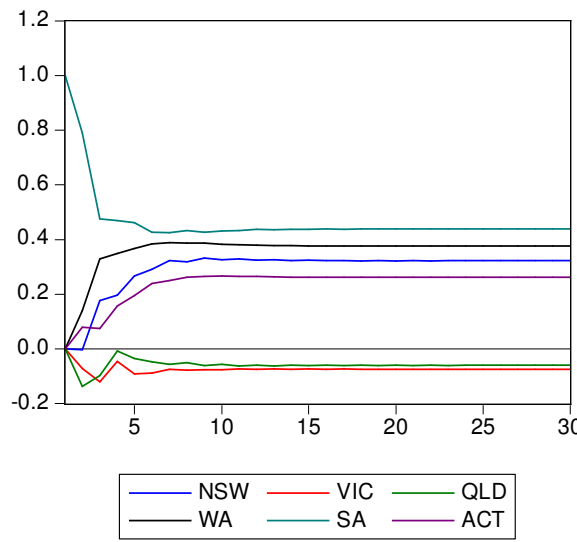

Response of VIC Non-Fundamental House Price Component to a One Unit Shock

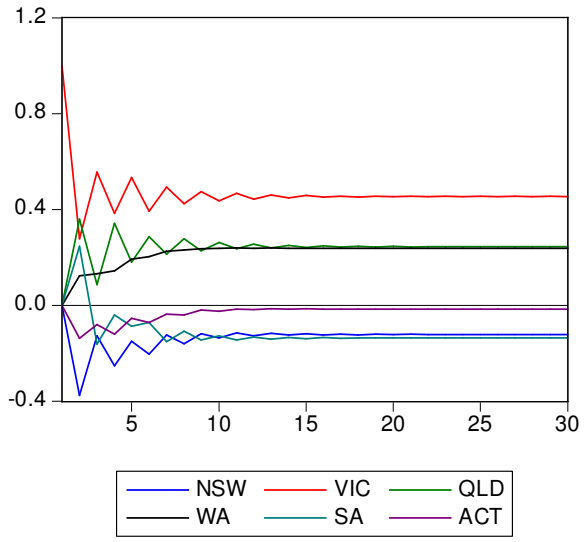

Response of WA Non-Fundamental House Price Component to a One Unit Shock

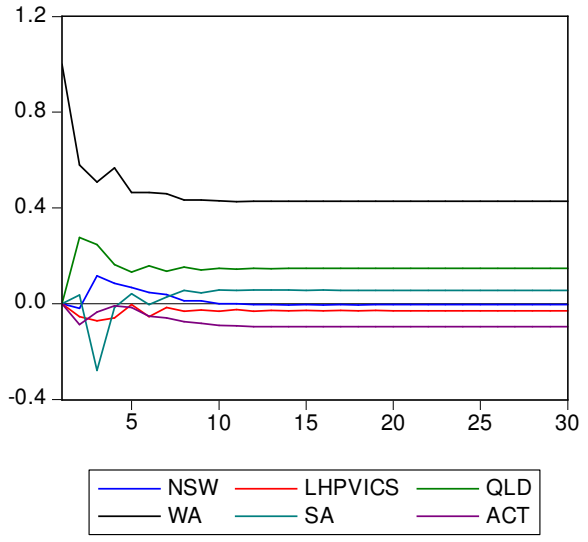

Response of ACT Non-Fundamental House Price Component to a One Unit Shock

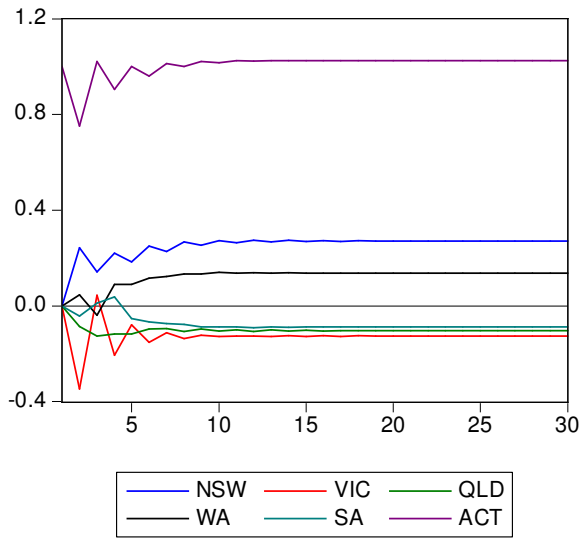


Response of NSW Non-Fundamental House Price Component to a One Unit Shock

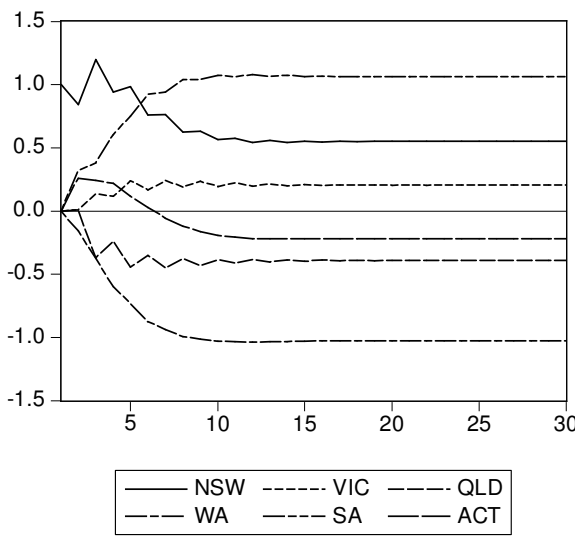

Response of QLD Non-Fundamental House Price Component to a One Unit Shock

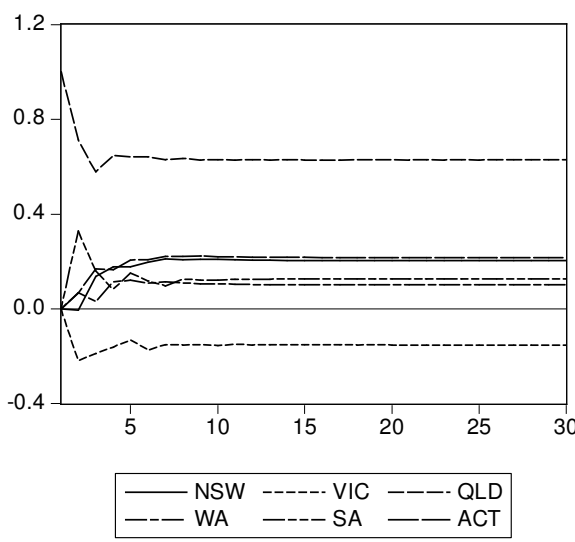

Response of SA Non-Fundamental House Price Component to a One Unit Shock

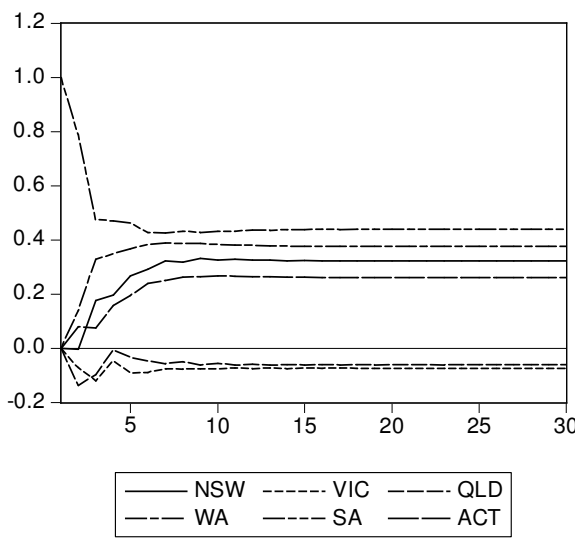

Response of VIC Non-Fundamental House Price Component to a One Unit Shock

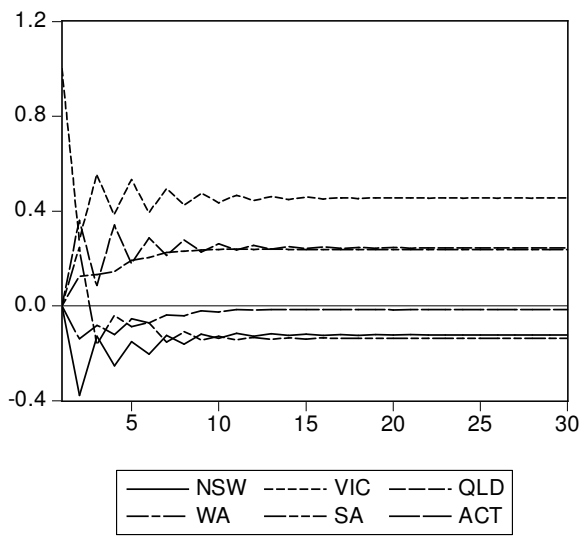

Response of WA Non-Fundamental House Price Component to a One Unit Shock

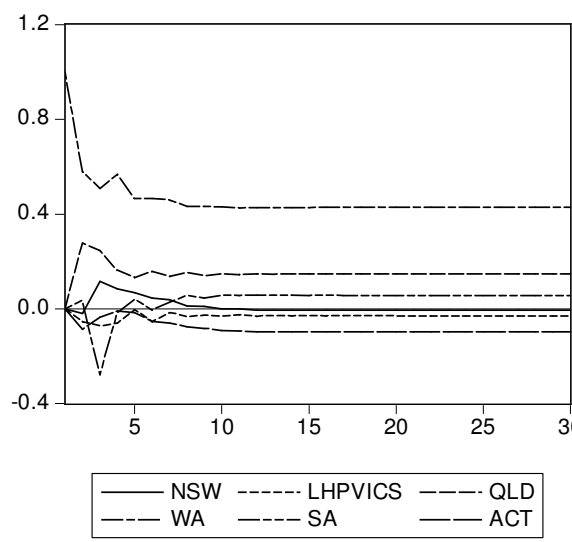

Response of ACT Non-Fundamental House Price Component to a One Unit Shock

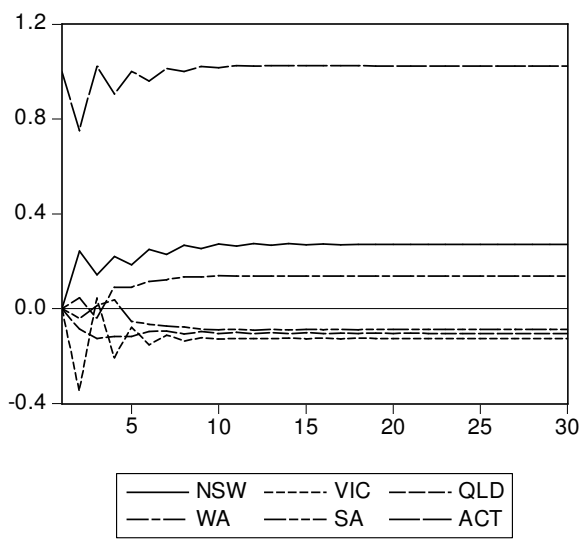


Table 1a. Summary Statistics on Key Variables: All Australia*

\begin{tabular}{|c|c|c|c|c|}
\hline & Mean & Variance & J-B & ADF \\
\hline$\Delta p_{t}$ & 0.010 & 0.001 & $\begin{array}{c}7.509 \\
(0.023)\end{array}$ & $\begin{array}{c}-4.327^{*} \\
(0,0,2)\end{array}$ \\
\hline$\Delta q_{t}$ & 0.017 & 0.0001 & 3.318 & $-7.096^{*}$ \\
$(\mathrm{DFD})$ & & & $(0.190)$ & $(\mathrm{c}, 0,0)$ \\
\hline$\Delta q_{t}$ & 0.017 & 0.0001 & 0.242 & $-7.615^{*}$ \\
$(\mathrm{DISPINC})$ & & & $(0.886)$ & $(\mathrm{c}, 0.0)$ \\
\hline$\pi_{t}$ & 4.702 & 0.018 & 7.598 & -2.609 \\
$(\mathrm{DFD})$ & & & $(0.022)$ & $(\mathrm{c}, \mathrm{t}, 2)$ \\
\hline$\pi_{t}$ & 4.689 & 0.018 & 8.542 & -2.580 \\
$(\mathrm{DISPINC})$ & & & $(0.014)$ & $(\mathrm{c}, \mathrm{t}, 2)$ \\
\hline$f_{t}$ & 0.011 & 0.00006 & 24.274 & $-5.305^{*}$ \\
& & & $(0.000)$ & $(\mathrm{c}, \mathrm{t}, 1)$ \\
\hline
\end{tabular}

* $\Delta p_{t}$ denotes the first difference in net $(\log )$ real house prices, $\Delta q_{t}$, is real income growth, DFD indicates that real Domestic Final Demand is used as a measure of $q_{t}$ and DISPINC that real disposable income is used as a measure of $q_{t}, \pi_{t}$ is the constructed (ln) real house price-income ratio with income proxied by DFD and DISPINC. $f_{t}$, is the real risk-free rate of return. The statistics above are computed on series with means included. J-B is the Jarque-Bera test for normality. Figures in parenthesis below the J-B statistics are significance levels. ADF is the augmented Dickey-Fuller statistic and is a test for a unit root in the series. An asterisk denotes rejection of the null of a unit root. Figures in parenthesis below the ADF test statistics denote the constant $(\mathrm{c})$, trend $(\mathrm{t})$ and lag $(\mathrm{n})$ properties of the test, where $\mathrm{c}$ indicates a constant, $\mathrm{t}$ a trend and $\mathrm{n}$ the number of lags. Critical values for the ADF test are: with no trend or intercept $-1.615(10 \%),-1.944(5 \%),-2.590$ (1\%); with intercept -2.584 (10\%), $-2.893(5 \%),-3.502(1 \%)$; with trend and intercept $-3.155(10 \%),-3.458(5 \%),-4.059$ (1\%). Data are from 1984:3 through 2008:2.

All Australia*

\begin{tabular}{|c|c|c|c|}
\hline Lag & $\begin{array}{c}\text { Autocorrelation } \\
\text { Coefficient of } \pi_{t}\end{array}$ & Q-Statistic & Probability \\
\hline 25 & -0.002 & 634.79 & 0.000 \\
\hline 26 & -0.033 & 634.94 & 0.000 \\
\hline 27 & -0.064 & 635.50 & 0.000 \\
\hline 28 & -0.081 & 636.39 & 0.000 \\
\hline 29 & -0.104 & 637.91 & 0.000 \\
\hline 30 & -0.116 & 639.81 & 0.000 \\
\hline 31 & -0.129 & 642.20 & 0.000 \\
\hline 32 & -0.132 & 644.76 & 0.000 \\
\hline 33 & -0.140 & 647.66 & 0.000 \\
\hline 34 & -0.148 & 650.97 & 0.000 \\
\hline 35 & -0.158 & 654.82 & 0.000 \\
\hline 36 & -0.166 & 659.12 & \\
\hline
\end{tabular}

*The Q-statistic relates to a test that the first $\mathrm{n}$ autocorrelation coefficients are zero, where $\mathrm{n}$ is the number of lags in column 1 and 'probability is the significance level at which the hypothesis is rejected. The first lag length reported is the lag at which predominately negative autocorrelation for the series begins. 
Table 1b. Summary Statistics on Key Variables: ACT*

\begin{tabular}{|c|c|c|c|c|}
\hline & Mean & Variance & J-B & ADF \\
\hline$\Delta p_{t}$ & 0.008 & 0.002 & 0.742 & $-4.561^{*}$ \\
& & & $(0.690)$ & $(0,0,1)$ \\
\hline$\Delta q_{t}$ & 0.010 & 0.0009 & 5.634 & $-12.547^{*}$ \\
$(\mathrm{SFD})$ & & & $(0.060)$ & $(\mathrm{c}, 0,0)$ \\
\hline$\pi_{t}$ & 4.527 & 0.029 & 2.214 & -2.102 \\
$(\mathrm{SFD})$ & & & $(0.331)$ & $(\mathrm{c}, \mathrm{t}, 2)$ \\
\hline$f_{t}$ & 0.011 & 0.00006 & 13.554 & $-7.627^{*}$ \\
& & & $(0.001)$ & $(\mathrm{c}, \mathrm{t}, 0)$ \\
\hline
\end{tabular}

* $\Delta p_{t}$ denotes the first difference in net $(\log )$ real house prices, $\Delta q_{t}$, is real income growth, SFD denotes real State Final Demand as a measure of $q_{t} . \quad \pi_{t}$ is the constructed (ln) real house price-income ratio with income proxied by SFD. $f_{t}$, is the real risk-free rate of return. The statistics above are computed on series with means included. J-B is the Jarque-Bera test for normality. Figures in parenthesis below the J-B statistics are significance levels. ADF is the augmented Dickey-Fuller statistic and is a test for a unit root in the series. An asterisk denotes rejection of the null of a unit root. Figures in parenthesis below the ADF test statistics denote the constant (c), trend ( $t)$ and lag (n) properties of the test, where $\mathrm{c}$ indicates a constant, $\mathrm{t}$ a trend and $\mathrm{n}$ the number of lags. Critical values for the ADF test are: with no trend or intercept $-1.615(10 \%),-1.944(5 \%),-2.590(1 \%)$; with intercept -2.584 (10\%), -2.893 (5\%), -3.502 (1\%); with trend and intercept -3.155 (10\%), -3.458 (5\%), -4.059 (1\%). Data are from 1984:3 through 2008:2.

$\mathrm{ACT}^{*}$

\begin{tabular}{|c|c|c|c|}
\hline Lag & $\begin{array}{c}\text { Autocorrelation } \\
\text { Coefficient of } \pi_{t}\end{array}$ & Q-Statistic & Probability \\
\hline 17 & -0.005 & 379.16 & 0.000 \\
\hline 18 & -0.072 & 379.78 & 0.000 \\
\hline 19 & -0.121 & 381.56 & 0.000 \\
\hline 20 & -0.150 & 384.32 & 0.000 \\
\hline 21 & -0.181 & 388.38 & 0.000 \\
\hline 22 & -0.188 & 392.83 & 0.000 \\
\hline 23 & -0.193 & 397.61 & 0.000 \\
\hline 24 & -0.197 & 402.64 & 0.000 \\
\hline 25 & -0.190 & 407.39 & 0.000 \\
\hline 26 & -0.205 & 413.00 & 0.000 \\
\hline 27 & -0.207 & 418.78 & 0.000 \\
\hline 28 & -0.217 & 425.24 & 0.000 \\
\hline 29 & -0.226 & 432.37 & 0.000 \\
\hline 30 & -0.220 & 439.25 & 0.000 \\
\hline 31 & -0.228 & 446.75 & 0.000 \\
\hline 32 & -0.225 & 454.16 & 0.000 \\
\hline 33 & -0.227 & 461.85 & 0.000 \\
\hline 34 & -0.221 & 469.20 & 0.000 \\
\hline 35 & -0.215 & 476.32 & 0.000 \\
\hline 36 & -0.214 & 483.48 & 0.000 \\
\hline
\end{tabular}

*The Q-statistic relates to a test that the first $\mathrm{n}$ autocorrelation coefficients are zero, where $\mathrm{n}$ is the number of lags in column 1 and 'probability is the significance level at which the hypothesis is rejected. The first lag length reported is the lag at which predominately negative autocorrelation for the series begins. 
Table 1c. Summary Statistics on Key Variables: NSW*

\begin{tabular}{|c|c|c|c|c|}
\hline & Mean & Variance & J-B & ADF \\
\hline$\Delta p_{t}$ & 0.010 & 0.002 & 38.352 & $-4.251^{*}$ \\
& & & $(0.000)$ & $(0,0,1)$ \\
\hline$\Delta q_{t}$ & 0.006 & 0.0002 & 4.052 & $-9.182^{*}$ \\
$(\mathrm{SFD})$ & & & $(0.132)$ & $(\mathrm{c}, 0,0)$ \\
\hline$\pi_{t}$ & 4.766 & 0.037 & 7.954 & -2.474 \\
$(\mathrm{SFD})$ & & & $(0.019)$ & $(\mathrm{c}, \mathrm{t}, 2)$ \\
\hline$f_{t}$ & 0.011 & 0.00006 & 29.286 & $-7.337^{*}$ \\
& & & $(0.000)$ & $(\mathrm{c}, \mathrm{t}, 1)$ \\
\hline
\end{tabular}

* See notes to first panel of Table 1b.

NSW*

\begin{tabular}{|c|c|c|c|}
\hline Lag & $\begin{array}{c}\text { Autocorrelation } \\
\text { Coefficient of } \pi_{t}\end{array}$ & Q-Statistic & Probability \\
\hline 25 & -0.002 & 634.79 & 0.000 \\
\hline 26 & -0.033 & 634.94 & 0.000 \\
\hline 27 & -0.064 & 635.50 & 0.000 \\
\hline 28 & -0.081 & 636.39 & 0.000 \\
\hline 29 & -0.104 & 637.91 & 0.000 \\
\hline 30 & -0.116 & 639.81 & 0.000 \\
\hline 31 & -0.129 & 642.20 & 0.000 \\
\hline 32 & -0.132 & 644.76 & 0.000 \\
\hline 33 & -0.140 & 647.66 & 0.000 \\
\hline 34 & -0.148 & 650.97 & 0.000 \\
\hline 35 & -0.158 & 654.82 & 0.000 \\
\hline 36 & -0.166 & 659.12 & 0.000 \\
\hline
\end{tabular}

* See notes to second panel of Table $1 \mathrm{~b}$. 
Table 1d. Summary Statistics on Key Variables: NT*

\begin{tabular}{|c|c|c|c|c|}
\hline & Mean & Variance & J-B & ADF \\
\hline$\Delta p_{t}$ & 0.012 & 0.002 & $\begin{array}{c}1.527 \\
(0.466)\end{array}$ & $\begin{array}{c}-7.500^{*} \\
(0,0,0)\end{array}$ \\
\hline$\Delta q_{t}$ & 0.013 & 0.002 & 13.797 & $-8.539^{*}$ \\
$(\mathrm{SFD})$ & & & $(0.001)$ & $(\mathrm{c}, 0,0)$ \\
\hline$\pi_{t}$ & 4.475 & 0.019 & 1.977 & -2.111 \\
$(\mathrm{SFD})$ & & & $(0.372)$ & $(\mathrm{c}, \mathrm{t}, 0)$ \\
\hline$f_{t}$ & 0.008 & 0.00004 & 115.372 & $-6.682^{*}$ \\
& & & $(0.000)$ & $(\mathrm{c}, \mathrm{t}, 1)$ \\
\hline
\end{tabular}

(1\%). Data are from 1994:1 through 2008:2.

\begin{tabular}{|c|c|c|c|}
\hline \multicolumn{5}{|l}{ NT $^{*}$} \\
\hline Lag & $\begin{array}{c}\text { Autocorrelation } \\
\text { Coefficient of } \pi_{t}\end{array}$ & Q-Statistic & Probability \\
\hline 14 & -0.062 & 166.98 & 0.000 \\
\hline 15 & -0.175 & 169.43 & 0.000 \\
\hline 16 & -0.231 & 173.82 & 0.000 \\
\hline 17 & -0.304 & 181.60 & 0.000 \\
\hline 18 & -0.343 & 191.76 & 0.000 \\
\hline 19 & -0.318 & 200.69 & 0.000 \\
\hline 20 & -0.315 & 209.73 & 0.000 \\
\hline 21 & -0.339 & 220.48 & 0.000 \\
\hline 22 & -0.341 & 231.64 & 0.000 \\
\hline 23 & -0.339 & 243.02 & 0.000 \\
\hline 24 & -0.378 & 257.60 & 0.000 \\
\hline
\end{tabular}

*See notes to second panel of Table $1 \mathrm{~b}$. 
Table 1e. Summary Statistics on Key Variables: QLD*

\begin{tabular}{|c|c|c|c|c|}
\hline & Mean & Variance & J-B & ADF \\
\hline$\Delta p_{t}$ & 0.011 & 0.001 & $\begin{array}{l}4.458 \\
(0.108)\end{array}$ & $\begin{array}{c}-4.393^{*} \\
(0,0,1)\end{array}$ \\
\hline$\Delta q_{t}$ & 0.012 & 0.0003 & 1.567 & $-10.346^{*}$ \\
$(\mathrm{SFD})$ & & & $(0.457)$ & $(\mathrm{c}, 0,0)$ \\
\hline$\pi_{t}$ & 4.508 & 0.012 & 3.033 & -1.639 \\
$(\mathrm{SFD})$ & & & $(0.220)$ & $(\mathrm{c}, \mathrm{t}, 0)$ \\
\hline$f_{t}$ & 0.011 & 0.00006 & 13.095 & $-7.775^{*}$ \\
& & & $(0.001)$ & $(\mathrm{c}, \mathrm{t}, 0)$ \\
\hline
\end{tabular}

*See notes to first panel of Table $1 \mathrm{~b}$.

\section{QLD*}

\begin{tabular}{|c|c|c|c|}
\hline Lag & $\begin{array}{l}\text { Autocorrelation } \\
\text { Coefficient of } \pi_{t}\end{array}$ & Q-Statistic & Probability \\
\hline 5 & -0.106 & 306.90 & 0.000 \\
\hline 6 & -0.007 & 336.31 & 0.000 \\
\hline 7 & -0.086 & 357.08 & 0.000 \\
\hline 8 & -0.152 & 370.04 & 0.000 \\
\hline 9 & 0.026 & 377.54 & 0.000 \\
\hline 10 & -0.147 & 380.57 & 0.000 \\
\hline 11 & -0.055 & 381.23 & 0.000 \\
\hline 12 & 0.085 & 381.23 & 0.000 \\
\hline 13 & -0.016 & 381.62 & 0.000 \\
\hline 14 & -0.028 & 383.15 & 0.000 \\
\hline 15 & -0.001 & 386.21 & 0.000 \\
\hline 16 & -0.050 & 391.17 & 0.000 \\
\hline 17 & -0.214 & 399.73 & 0.000 \\
\hline 18 & -0.080 & 412.41 & 0.000 \\
\hline 19 & -0.082 & 430.29 & 0.000 \\
\hline 20 & 0.021 & 452.40 & 0.000 \\
\hline 21 & 0.100 & 476.97 & 0.000 \\
\hline 22 & -0.138 & 504.30 & 0.000 \\
\hline 23 & 0.062 & 532.74 & 0.000 \\
\hline 24 & 0.034 & 561.64 & 0.000 \\
\hline 25 & -0.021 & 589.42 & 0.000 \\
\hline 26 & -0.111 & 618.00 & 0.000 \\
\hline 27 & -0.087 & 646.32 & 0.000 \\
\hline 28 & -0.001 & 673.60 & 0.000 \\
\hline 29 & -0.095 & 699.70 & 0.000 \\
\hline 30 & -0.073 & 724.00 & 0.000 \\
\hline 31 & 0.072 & 745.12 & 0.000 \\
\hline 32 & -0.007 & 763.27 & 0.000 \\
\hline 33 & -0.006 & 778.60 & 0.000 \\
\hline 34 & -0.013 & 791.18 & 0.000 \\
\hline 35 & -0.018 & 801.64 & 0.000 \\
\hline 36 & 0.008 & 809.66 & 0.000 \\
\hline
\end{tabular}

*See notes to second panel of Table $1 \mathrm{~b}$. 
Table 1f. Summary Statistics on Key Variables: SA*

\begin{tabular}{|c|c|c|c|c|}
\hline & Mean & Variance & J-B & ADF \\
\hline$\Delta h p_{t}$ & 0.008 & 0.001 & 6.152 & $-2.77^{*}$ \\
& & & $(0.046)$ & $(0,0,1)$ \\
\hline$\Delta q_{t}$ & 0.005 & 0.0003 & 8.910 & $-12.44^{*}$ \\
$(\mathrm{SFD})$ & & & $(0.12)$ & $(\mathrm{c}, 0,0)$ \\
\hline$\pi_{t}$ & 4.560 & 0.019 & 7.633 & -0.280 \\
$(\mathrm{SFD})$ & & & $(0.022)$ & $(\mathrm{c}, \mathrm{t}, 1)$ \\
\hline$f_{t}$ & 0.011 & 0.00006 & 11.040 & $-4.866^{*}$ \\
& & & $(0.004)$ & $(\mathrm{c}, \mathrm{t}, 0)$ \\
\hline
\end{tabular}

* See notes to first panel of Table $1 \mathrm{~b}$.

$\mathrm{SA}^{*}$

\begin{tabular}{|c|c|c|c|}
\hline Lag & $\begin{array}{c}\text { Autocorrelation } \\
\text { Coefficient of } \pi_{t}\end{array}$ & Q-Statistic & Probability \\
\hline 19 & -0.030 & 546.43 & 0.000 \\
\hline 20 & -0.074 & 547.11 & 0.000 \\
\hline 21 & -0.138 & 549.47 & 0.000 \\
\hline 22 & -0.181 & 553.61 & 0.000 \\
\hline 23 & -0.221 & 559.85 & 0.000 \\
\hline 24 & -0.247 & 567.74 & 0.000 \\
\hline 25 & -0.267 & 577.11 & 0.000 \\
\hline 26 & -0.297 & 588.87 & 0.000 \\
\hline 27 & -0.310 & 601.89 & 0.000 \\
\hline 28 & -0.323 & 616.20 & 0.000 \\
\hline 29 & -0.334 & 631.79 & 0.000 \\
\hline 30 & -0.335 & 647.66 & 0.000 \\
\hline 31 & -0.335 & 663.82 & 0.000 \\
\hline 32 & -0.311 & 677.99 & 0.000 \\
\hline 33 & -0.304 & 691.68 & 0.000 \\
\hline 34 & -0.294 & 704.74 & 0.000 \\
\hline 35 & -0.283 & 717.09 & 0.000 \\
\hline 36 & -0.286 & 729.89 & \\
\hline
\end{tabular}

* See notes to second panel of Table $1 \mathrm{~b}$. 
Table 1g. Summary Statistics on Key Variables: TAS*

\begin{tabular}{|c|c|c|c|c|}
\hline & Mean & Variance & J-B & ADF \\
\hline$\Delta p_{t}$ & 0.013 & 0.003 & $\begin{array}{c}62.805 \\
(0.000)\end{array}$ & $\begin{array}{c}-8.747^{*} \\
(0,0,0)\end{array}$ \\
\hline$\Delta q_{t}$ & 0.006 & 0.0009 & 15.774 & $-13.632^{*}$ \\
$(\mathrm{SFD})$ & & & $(0.000)$ & $(\mathrm{c}, 0,0)$ \\
\hline$\pi_{t}$ & 4.608 & 0.040 & 9.360 & -1.818 \\
$(\mathrm{SFD})$ & & & $(0.009)$ & $(\mathrm{c}, \mathrm{t}, 0)$ \\
\hline$f_{t}$ & 0.009 & 0.00005 & 73.300 & $-7.483^{*}$ \\
& & & $(0.000)$ & $(\mathrm{c}, \mathrm{t}, 0)$ \\
\hline
\end{tabular}

* See notes to first panel of Table 1b. Critical values for the ADF test are: with no trend or intercept $-1.614(10 \%),-1.946(5 \%)$,

$-2.600(1 \%)$; with intercept $-2.590(10 \%),-2.906(5 \%),-3.532(1 \%)$; with trend and intercept $-3.166(10 \%),-3.476(5 \%),-4.097$

(1\%). Data are from 1991:1 through 2008:2.

$\mathrm{TAS}^{*}$

\begin{tabular}{|c|c|c|c|}
\hline Lag & $\begin{array}{c}\text { Autocorrelation } \\
\text { Coefficient of } \pi_{t}\end{array}$ & Q-Statistic & Probability \\
\hline 18 & -0.037 & 393.76 & 0.000 \\
\hline 19 & -0.101 & 394.76 & 0.000 \\
\hline 20 & -0.147 & 396.93 & 0.000 \\
\hline 21 & -0.185 & 400.42 & 0.000 \\
\hline 22 & -0.211 & 405.08 & 0.000 \\
\hline 23 & -0.230 & 410.70 & 0.000 \\
\hline 24 & -0.233 & 416.61 & 0.000 \\
\hline 25 & -0.242 & 423.12 & 0.000 \\
\hline 26 & -0.256 & 430.58 & 0.000 \\
\hline 27 & -0.255 & 438.16 & 0.000 \\
\hline 28 & -0.254 & 445.86 & 0.000 \\
\hline
\end{tabular}

*See notes to second panel of Table $1 \mathrm{~b}$. 
Table 1h. Summary Statistics on Key Variables: VIC*

\begin{tabular}{|c|c|c|c|c|}
\hline & Mean & Variance & J-B & ADF \\
\hline$\Delta p_{t}$ & 0.010 & 0.003 & 7.959 & $-5.785^{*}$ \\
& & & $(0.019)$ & $(0,0,1)$ \\
\hline$\Delta q_{t}$ & 0.007 & 0.0003 & 16.585 & $-10.400^{*}$ \\
$(\mathrm{SFD})$ & & & $(0.000)$ & $(\mathrm{c}, 0,0)$ \\
\hline$\pi_{t}$ & 4.705 & 0.021 & 3.781 & -2.125 \\
$(\mathrm{SFD})$ & & & $(0.151)$ & $(\mathrm{c}, \mathrm{t}, 1)$ \\
\hline$f_{t}$ & 0.011 & 0.00006 & 31.576 & $-4.892^{*}$ \\
& & & $(0.000)$ & $(\mathrm{c}, \mathrm{t}, 1)$ \\
\hline
\end{tabular}

* See notes to first panel of Table $1 \mathrm{~b}$.

VIC*

\begin{tabular}{|c|c|c|c|}
\hline Lag & $\begin{array}{c}\text { Autocorrelation } \\
\text { Coefficient of } \pi_{t}\end{array}$ & Q-Statistic & Probability \\
\hline 27 & -0.009 & 713.21 & 0.000 \\
\hline 28 & -0.008 & 713.22 & 0.000 \\
\hline 29 & -0.047 & 713.53 & 0.000 \\
\hline 30 & -0.029 & 713.65 & 0.000 \\
\hline 31 & -0.045 & 713.94 & 0.000 \\
\hline 32 & -0.023 & 714.02 & 0.000 \\
\hline 33 & -0.037 & 714.23 & 0.000 \\
\hline 34 & -0.026 & 714.33 & 0.000 \\
\hline 35 & -0.042 & 714.61 & 0.000 \\
\hline 36 & -0.038 & 714.84 & 0.000 \\
\hline
\end{tabular}

*See notes to second panel of Table $1 \mathrm{~b}$. 
Table 1i. Summary Statistics on Key Variables: WA*

\begin{tabular}{|c|c|c|c|c|}
\hline & Mean & Variance & J-B & ADF \\
\hline$\Delta p_{t}$ & 0.013 & 0.002 & 22.800 & $-6.301^{*}$ \\
& & & $(0.000)$ & $(0,0,0)$ \\
\hline$\Delta q_{t}$ & 0.011 & 0.0006 & 1.219 & $-9.668^{*}$ \\
$(\mathrm{SFD})$ & & & $(0.544)$ & $(\mathrm{c}, 0,0)$ \\
\hline$\pi_{t}$ & 4.612 & 0.020 & 24.798 & -2.338 \\
$(\mathrm{SFD})$ & & & $(0.000)$ & $(\mathrm{c}, \mathrm{t}, 0)$ \\
\hline$f_{t}$ & 0.011 & 0.00006 & 18.702 & $-3.585^{*}$ \\
& & & $(0.000)$ & $(\mathrm{c}, \mathrm{t}, 2)$ \\
\hline
\end{tabular}

* See notes to first panel of Table $1 \mathrm{~b}$.

WA*

\begin{tabular}{|c|c|c|c|}
\hline Lag & $\begin{array}{c}\text { Autocorrelation } \\
\text { Coefficient of } \pi_{t}\end{array}$ & Q-Statistic & Probability \\
\hline 21 & -0.019 & 434.29 & 0.000 \\
\hline 22 & -0.041 & 434.51 & 0.000 \\
\hline 23 & -0.073 & 435.19 & 0.000 \\
\hline 24 & -0.100 & 436.48 & 0.000 \\
\hline 25 & -0.125 & 438.54 & 0.000 \\
\hline 26 & -0.138 & 441.08 & 0.000 \\
\hline 27 & -0.151 & 444.15 & 0.000 \\
\hline 28 & -0.169 & 448.09 & 0.000 \\
\hline 29 & -0.184 & 452.81 & 0.000 \\
\hline 30 & -0.190 & 457.91 & 0.000 \\
\hline 31 & -0.183 & 462.74 & 0.000 \\
\hline 32 & -0.174 & 467.16 & 0.000 \\
\hline 33 & -0.175 & 471.70 & 0.000 \\
\hline 34 & -0.178 & 476.46 & 0.000 \\
\hline 35 & -0.178 & 481.32 & 0.000 \\
\hline 36 & -0.174 & 486.07 & 0.000 \\
\hline
\end{tabular}

*See notes to second panel of Table $1 \mathrm{~b}$. 
Table 2. Cointegration Tests: (LN) Real House Price: (LN) Real Final Demand*

\begin{tabular}{|c|c|c|c|c|}
\hline & $\begin{array}{c}\text { Johansen } \\
\text { Trace Test of } \\
\text { No } \\
\text { Cointegration }\end{array}$ & $\begin{array}{c}\text { Johansen } \\
\text { Eigenvalue } \\
\text { Test of No } \\
\text { Cointegration }\end{array}$ & $\begin{array}{c}\text { Model } \\
\text { Specification }\end{array}$ & $\begin{array}{c}\text { Lag } \\
\text { Specification } \\
\text { for } \\
\text { Differenced } \\
\text { Endogenous } \\
\text { Variables }\end{array}$ \\
\hline All Australia & $\begin{array}{c}23.080 * \\
\text { prob:0.001 }\end{array}$ & $\begin{array}{c}22.672 * \\
\text { prob: } 0.000\end{array}$ & $\begin{array}{l}\text { No intercept } \\
\text { or trend }\end{array}$ & $1-1$ \\
\hline ACT & $\begin{array}{c}15.222 * \\
\text { prob:0.016 }\end{array}$ & $\begin{array}{c}15.060 * \\
\text { prob:0.010 }\end{array}$ & $\begin{array}{l}\text { No intercept } \\
\text { or trend }\end{array}$ & $1-2$ \\
\hline NSW & $\begin{array}{c}15.267 * \\
\text { prob: } 0.016\end{array}$ & $\begin{array}{c}14.404^{*} \\
\text { prob:0.013 }\end{array}$ & $\begin{array}{l}\text { No intercept } \\
\text { or trend }\end{array}$ & $1-1$ \\
\hline NT & $\begin{array}{c}19.955^{*} \\
\text { prob: } 0.002\end{array}$ & $\begin{array}{c}19.585^{*} \\
\text { prob:0.001 }\end{array}$ & $\begin{array}{l}\text { No intercept } \\
\text { or trend }\end{array}$ & $1-4$ \\
\hline QLD & $\begin{array}{c}14.900 * \\
\text { prob:0.018 }\end{array}$ & $\begin{array}{c}13.891 * \\
\text { prob:0.017 }\end{array}$ & $\begin{array}{l}\text { No intercept } \\
\text { or trend }\end{array}$ & $1-2$ \\
\hline SA & $\begin{array}{c}23.892 * \\
\text { prob:0.015 }\end{array}$ & $\begin{array}{c}18.770^{*} \\
\text { prob: } 0.017\end{array}$ & $\begin{array}{c}\text { Intercept no } \\
\text { trend }\end{array}$ & $1-2$ \\
\hline TAS & $\begin{array}{c}12.915^{*} \\
\text { prob: } 0.040\end{array}$ & $\begin{array}{c}11.899 * \\
\text { prob: } 0.038\end{array}$ & $\begin{array}{l}\text { No intercept } \\
\text { or trend }\end{array}$ & $1-3$ \\
\hline VIC & $\begin{array}{c}14.387^{*} \\
\text { prob: } 0.022\end{array}$ & $\begin{array}{c}13.830^{*} \\
\text { prob: } 0.017\end{array}$ & $\begin{array}{l}\text { No intercept } \\
\text { or trend }\end{array}$ & $1-1$ \\
\hline WA & $\begin{array}{c}14.107 * \\
\text { prob:0.026 }\end{array}$ & $\begin{array}{c}13.858^{*} \\
\text { prob: } 0.017\end{array}$ & $\begin{array}{l}\text { No intercept } \\
\text { or trend }\end{array}$ & $1-10$ \\
\hline
\end{tabular}

*Prob denotes probability values. In each case the null hypothesis is that the variables are not cointegrated. An asterisk denotes rejection of the null at the $5 \%$ significance level. The sample periods are as noted above in Table 1a through 1 i. 
Table 3.VAR Statistics and Tests for the Time-Varying Discount Rate Present Value Model*: $\mathbf{z}_{t+1}=\mathbf{A z}_{t}+\varepsilon_{t+1}$

All Australia

\begin{tabular}{|c|c|c|c|c|c|c|c|c|c|c|c|c|}
\hline $\mathbf{z}_{t}$ & $\pi_{t-1}$ & $\Delta q_{t-2}$ & $f_{t-1}$ & $\pi_{t-2}$ & $\Delta q_{t-3}$ & $f_{t-2}$ & $\pi_{t-3}$ & $\Delta q_{t-4}$ & $f_{t-3}$ & $Q(4)$ & $\begin{array}{l}N-L \\
\text { Wald }\end{array}$ & $L$ Wald \\
\hline$\pi_{t}$ & $\begin{array}{l}0.823^{*} \\
(0.102)\end{array}$ & $\begin{array}{c}0.316 \\
(0.371)\end{array}$ & $\begin{array}{l}-0.830 \\
(0.585)\end{array}$ & $\begin{array}{l}0.582^{*} \\
(0.144)\end{array}$ & $\begin{array}{c}0.103 \\
(0.360)\end{array}$ & $\begin{array}{l}-1.643^{*} \\
(0.606)\end{array}$ & $\begin{array}{c}-0.502 * \\
(0.105)\end{array}$ & $\begin{array}{c}0.276 \\
(0.306)\end{array}$ & $\begin{array}{c}0.705 \\
(0.624)\end{array}$ & $\begin{array}{c}6.031 \\
(0.197)\end{array}$ & $\begin{array}{l}44.326 \\
(0.000)\end{array}$ & $\begin{array}{l}76.558 \\
(0.000)\end{array}$ \\
\hline$\Delta q_{t-1}$ & $\begin{array}{l}0.102 * \\
(0.030)\end{array}$ & $\begin{array}{l}0.255^{*} \\
(0.109)\end{array}$ & $\begin{array}{l}0.407 * \\
(0.172)\end{array}$ & $\begin{array}{l}-0.027 \\
(0.042)\end{array}$ & $\begin{array}{r}0.128 \\
(0.106)\end{array}$ & $\begin{array}{l}-0.121 \\
(0.178)\end{array}$ & $\begin{array}{c}-0.061 * \\
(0.030)\end{array}$ & $\begin{array}{l}-0.085 \\
(0.090)\end{array}$ & $\begin{array}{l}-0.125 \\
(0.183)\end{array}$ & $\begin{array}{c}1.961 \\
(0.743)\end{array}$ & & \\
\hline$f_{t}$ & $\begin{array}{l}-0.016 \\
(0.020)\end{array}$ & $\begin{array}{r}-0.067 \\
(0.071)\end{array}$ & $\begin{array}{l}0.213^{*} \\
(0.112)\end{array}$ & $\begin{array}{c}0.011 \\
(0.028)\end{array}$ & $\begin{array}{c}-0.052 \\
(0.069)\end{array}$ & $\begin{array}{l}0.242^{*} \\
(0.116)\end{array}$ & $\begin{array}{c}0.003 \\
(0.020)\end{array}$ & $\begin{array}{c}0.047 \\
(0.058)\end{array}$ & $\begin{array}{l}0.270^{*} \\
(0.119)\end{array}$ & $\begin{array}{c}2.245 \\
(0.691)\end{array}$ & & \\
\hline
\end{tabular}

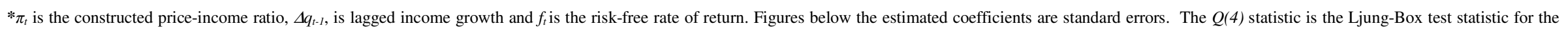

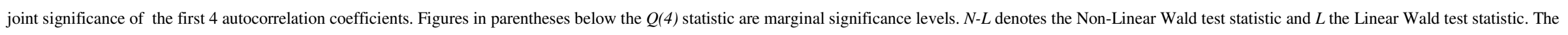

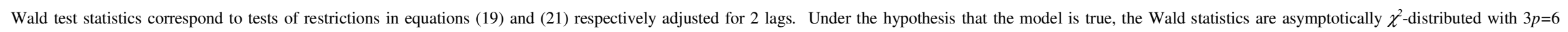
degrees of freedom; marginal significance levels appear in parentheses below the reported Wald statistics. * denotes significance of coefficient estimates at either $1 \% .5 \%$ or $10 \%$ levels of significance. 
ACT

\begin{tabular}{|c|c|c|c|c|c|c|c|c|c|}
\hline $\mathbf{z}_{t}$ & $\pi_{t-1}$ & $\Delta q_{t-2}$ & $f_{t-1}$ & $\pi_{t-2}$ & $\Delta q_{t-3}$ & $f_{t-2}$ & $Q(4)$ & $\begin{array}{c}N-L \\
\text { Wald }\end{array}$ & L Wald \\
\hline$\pi_{t}$ & $\begin{array}{c}0.818^{*} \\
(0.118)\end{array}$ & $\begin{array}{c}-0.017 \\
(0.191)\end{array}$ & $\begin{array}{c}1.052^{* *} \\
(0.681)\end{array}$ & $\begin{array}{c}0.111 \\
(0.116)\end{array}$ & $\begin{array}{c}0.088 \\
(0.164)\end{array}$ & $\begin{array}{c}0.435 \\
(0.691)\end{array}$ & $\begin{array}{c}5.057 \\
(0.282)\end{array}$ & $\begin{array}{c}35.334 \\
(0.000)\end{array}$ & $\begin{array}{c}13.645 \\
(0.034)\end{array}$ \\
\hline \multirow{2}{*}{$\Delta q_{t-1}$} & $\begin{array}{c}0.043 \\
(0.072)\end{array}$ & $\begin{array}{c}-0.134 \\
(0.116)\end{array}$ & $\begin{array}{c}0.598 \\
(0.415)\end{array}$ & $\begin{array}{c}-0.037 \\
(0.071)\end{array}$ & $\begin{array}{c}-0.015 \\
(0.100)\end{array}$ & $\begin{array}{c}-0.446 \\
(0.421)\end{array}$ & $\begin{array}{c}2.077 \\
(0.722)\end{array}$ & & \\
\hline$f_{t}$ & -0.026 & -0.032 & $0.320 *$ & $0.033 *$ & -0.007 & 0.285 \\
$(0.018)$ & $(0.029)$ & $(0.103)$ & $(0.017)$ & $(0.025)$ & $\begin{array}{c}0.104) \\
(0.138)\end{array}$ & & \\
\hline
\end{tabular}

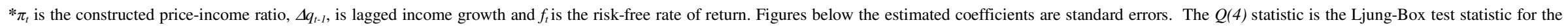

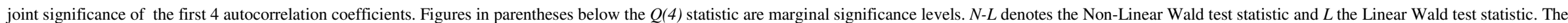

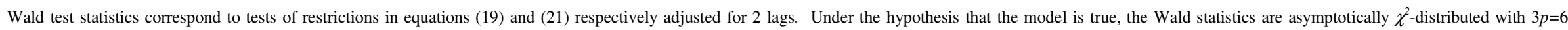
degrees of freedom; marginal significance levels appear in parentheses below the reported Wald statistics. * denotes significance of coefficient estimates at either $1 \% .5 \%$ or $10 \%$ levels of significance. 
NSW

\begin{tabular}{|c|c|c|c|c|c|c|c|c|c|c|c|c|}
\hline $\mathbf{z}_{t}$ & $\pi_{t-1}$ & $\Delta q_{t-2}$ & $f_{t-1}$ & $\pi_{t-2}$ & $\Delta q_{t-3}$ & $f_{t-2}$ & $\pi_{t-3}$ & $\Delta q_{t-4}$ & $f_{t-3}$ & $Q(4)$ & $\begin{array}{c}N-L \\
\text { Wald }\end{array}$ & $L$ Wald \\
\hline$\pi_{t}$ & $\begin{array}{l}0.066^{*} \\
(0.101)\end{array}$ & $\begin{array}{c}0.257 \\
(0.358)\end{array}$ & $\begin{array}{l}-0.528 \\
(0.687)\end{array}$ & $\begin{array}{c}0.445 \\
(0.146)\end{array}$ & $\begin{array}{c}0.453 \\
(0.348)\end{array}$ & $\begin{array}{l}-1.976^{*} \\
(0.705)\end{array}$ & $\begin{array}{c}-0.402 * \\
(0.101)\end{array}$ & $\begin{array}{c}0.355 \\
(0.319)\end{array}$ & $\begin{array}{c}0.020 \\
(0.726)\end{array}$ & $\begin{array}{c}4.768 \\
(0.312)\end{array}$ & $\begin{array}{l}88.943 \\
(0.000)\end{array}$ & $\begin{array}{l}44.474 \\
(0.000)\end{array}$ \\
\hline$\Delta q_{t-1}$ & $\begin{array}{l}0.087 * \\
(0.030)\end{array}$ & $\begin{array}{c}0.074 \\
(0.107)\end{array}$ & $\begin{array}{c}0.169 \\
(0.206)\end{array}$ & $\begin{array}{l}-0.054 \\
(0.044)\end{array}$ & $\begin{array}{c}0.035 \\
(0.105)\end{array}$ & $\begin{array}{c}0.341 * * \\
(0.211)\end{array}$ & $\begin{array}{l}-0.020 \\
(0.030)\end{array}$ & $\begin{array}{l}-0.105 \\
(0.096)\end{array}$ & $\begin{array}{l}-0.039 \\
(0.218)\end{array}$ & $\begin{array}{c}2.101 \\
(0.717)\end{array}$ & & \\
\hline$f_{t}$ & $\begin{array}{l}-0.020 \\
(0.015)\end{array}$ & $\begin{array}{l}-0.133^{*} \\
(0.053)\end{array}$ & $\begin{array}{l}0.243^{*} \\
(0.101)\end{array}$ & $\begin{array}{c}0.031 \\
(0.022)\end{array}$ & $\begin{array}{c}0.018 \\
(0.051)\end{array}$ & $\begin{array}{c}0.123 \\
(0.104)\end{array}$ & $\begin{array}{c}-0.012 \\
(0.015)\end{array}$ & $\begin{array}{c}0.026 \\
(0.047)\end{array}$ & $\begin{array}{l}0.375^{*} \\
(0.107)\end{array}$ & $\begin{array}{c}1.558 \\
(0.817)\end{array}$ & & \\
\hline
\end{tabular}

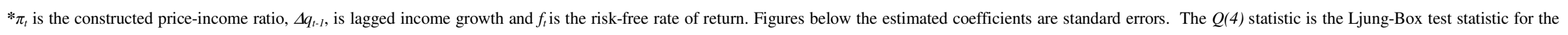

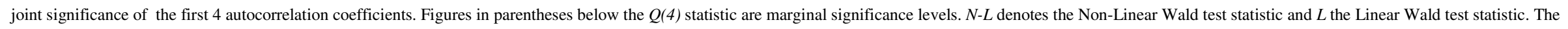

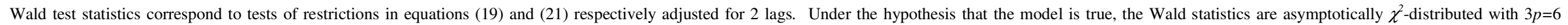
degrees of freedom; marginal significance levels appear in parentheses below the reported Wald statistics. $*$ denotes significance of coefficient estimates at either $1 \% .5 \%$ or $10 \%$ levels of significance. 


\section{NT}

\begin{tabular}{|c|c|c|c|c|c|c|c|c|c|}
\hline $\mathbf{z}_{t}$ & $\pi_{t-1}$ & $\Delta q_{t-2}$ & $f_{t-1}$ & $\pi_{t-2}$ & $\Delta q_{t-3}$ & $f_{t-2}$ & $Q(4)$ & $\begin{array}{c}N-L \\
\text { Wald }\end{array}$ & $L$ Wald \\
\hline$\pi_{t}$ & $\begin{array}{l}0.838^{*} \\
(0.204)\end{array}$ & $\begin{array}{c}0.067 \\
(0.308)\end{array}$ & $\begin{array}{c}0.075 \\
(1.558)\end{array}$ & $\begin{array}{c}0.034 \\
(0.196)\end{array}$ & $\begin{array}{c}0.202 \\
(0.206)\end{array}$ & $\begin{array}{c}-0.460 \\
(1.558)\end{array}$ & $\begin{array}{c}2.013 \\
(0.733)\end{array}$ & $\begin{array}{c}19.623 \\
(0.003)\end{array}$ & $\begin{array}{r}8.781 \\
(0.186)\end{array}$ \\
\hline$\Delta q_{t-1}$ & $\begin{array}{c}-0.010 \\
(0.135)\end{array}$ & $\begin{array}{c}-0.203 \\
(0.203)\end{array}$ & $\begin{array}{c}1.122 \\
(1.028)\end{array}$ & $\begin{array}{c}0.038 \\
(0.129)\end{array}$ & $\begin{array}{c}-0.061 \\
(0.136)\end{array}$ & $\begin{array}{c}0.329 \\
(1.027)\end{array}$ & $\begin{array}{c}3.430 \\
(0.489)\end{array}$ & & \\
\hline$f_{t}$ & $\begin{array}{c}-0.008 \\
(0.018)\end{array}$ & $\begin{array}{c}-0.019 \\
(0.027)\end{array}$ & $\begin{array}{c}0.183 \\
(0.136)\end{array}$ & $\begin{array}{c}0.014 \\
(0.017)\end{array}$ & $\begin{array}{l}0.030^{*} \\
(0.017)\end{array}$ & $\begin{array}{c}-0.073 \\
(0.136)\end{array}$ & $\begin{array}{c}1.292 \\
(0.863)\end{array}$ & & \\
\hline
\end{tabular}

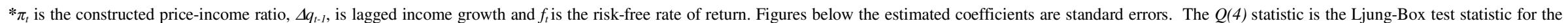

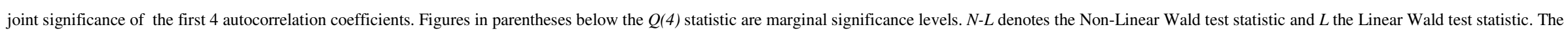

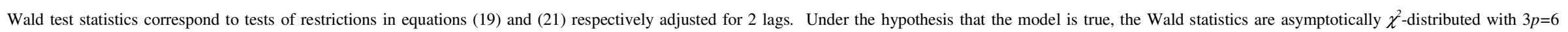
degrees of freedom; marginal significance levels appear in parentheses below the reported Wald statistics. * denotes significance of coefficient estimates at either $1 \% .5 \%$ or $10 \%$ levels of significance. 


\section{QLD}

\begin{tabular}{|c|c|c|c|c|c|c|c|c|c|}
\hline $\mathrm{Z}_{t}$ & $\pi_{t-1}$ & $\Delta q_{t-2}$ & $f_{t-1}$ & $\pi_{t-2}$ & $\Delta q_{t-3}$ & $f_{t-2}$ & $Q(4)$ & $\begin{array}{l}N-L \\
\text { Wald }\end{array}$ & $L$ Wald \\
\hline$\pi_{t}$ & $\begin{array}{l}1.007 * \\
(0.114)\end{array}$ & $\begin{array}{c}0.402 \\
(0.279)\end{array}$ & $\begin{array}{l}-0.999 * \\
(0.611)\end{array}$ & $\begin{array}{l}-0.070 \\
(0.117)\end{array}$ & $\begin{array}{l}-0.131 \\
(0.252)\end{array}$ & $\begin{array}{c}0.356 \\
(0.606)\end{array}$ & $\begin{array}{c}3.363 \\
(0.499)\end{array}$ & $\begin{array}{l}12.709 \\
(0.048)\end{array}$ & $\begin{array}{l}16.343 \\
(0.012)\end{array}$ \\
\hline$\Delta q_{t-1}$ & $\begin{array}{l}0.137 * \\
(0.045)\end{array}$ & $\begin{array}{c}0.017 \\
(0.110)\end{array}$ & $\begin{array}{c}0.248 \\
(0.242)\end{array}$ & $\begin{array}{c}-0.109^{*} \\
(0.046)\end{array}$ & $\begin{array}{c}-0.011 \\
(0.099)\end{array}$ & $\begin{array}{c}-0.374 * * \\
(0.240)\end{array}$ & $\begin{array}{c}0.610 \\
(0.962)\end{array}$ & & \\
\hline$f_{t}$ & $\begin{array}{l}-0.003 \\
(0.019)\end{array}$ & $\begin{array}{l}-0.054 \\
(0.047)\end{array}$ & $\begin{array}{l}0.289^{*} \\
(0.104)\end{array}$ & $\begin{array}{c}0.003 \\
(0.020)\end{array}$ & $\begin{array}{c}0.007 \\
(0.043)\end{array}$ & $\begin{array}{l}0.386^{*} \\
(0.103)\end{array}$ & $\begin{array}{c}7.378 \\
(0.117)\end{array}$ & & \\
\hline
\end{tabular}

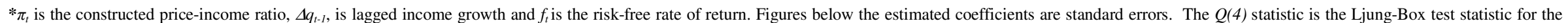

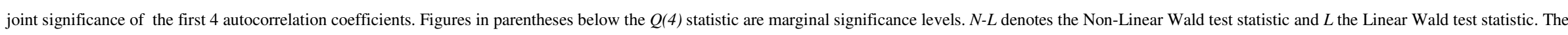

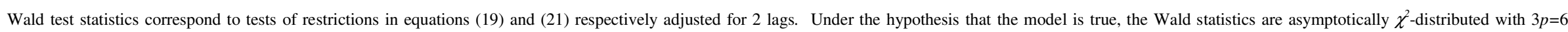
degrees of freedom; marginal significance levels appear in parentheses below the reported Wald statistics. * denotes significance of coefficient estimates at either $1 \% .5 \%$ or $10 \%$ levels of significance. 
SA

\begin{tabular}{|c|c|c|c|c|c|c|c|c|c|}
\hline $\mathrm{z}_{t}$ & $\pi_{t-1}$ & $\Delta q_{t-2}$ & $f_{t-1}$ & $\pi_{t-2}$ & $\Delta q_{t-3}$ & $f_{t-2}$ & $Q(4)$ & $\begin{array}{c}N-L \\
\text { Wald }\end{array}$ & L Wald \\
\hline$\pi_{t}$ & $\begin{array}{c}0.757^{*} \\
(0.115)\end{array}$ & $\begin{array}{c}0.034 \\
(0.244)\end{array}$ & $\begin{array}{c}-1.137^{*} \\
(0.515)\end{array}$ & $\begin{array}{c}0.249^{*} \\
(0.119)\end{array}$ & $\begin{array}{c}0.077 \\
(0, .222)\end{array}$ & $\begin{array}{c}-0.056 \\
(0.522)\end{array}$ & $\begin{array}{c}5.835 \\
(0.211)\end{array}$ & $\begin{array}{c}14.114 \\
(0.028)\end{array}$ & $\begin{array}{c}19.229 \\
(0.004)\end{array}$ \\
\hline \multirow{2}{*}{$\Delta q_{t-1}$} & $\begin{array}{c}0.144^{*} \\
(0.051)\end{array}$ & $\begin{array}{r}-0.049 \\
(0.110)\end{array}$ & $\begin{array}{c}0.156 \\
(0.232)\end{array}$ & $\begin{array}{c}0.144^{*} \\
(0.051)\end{array}$ & $\begin{array}{c}0.060 \\
(0.099)\end{array}$ & $\begin{array}{c}-0.170 \\
(0.235)\end{array}$ & $\begin{array}{c}5.691 \\
(0.223)\end{array}$ & & \\
\hline$f_{t}$ & $-0.037^{*}$ & $-0.119 *$ & $0.294^{*}$ & $0.037^{*}$ & 0.025 & $0.331^{*}$ & 3.802 \\
$(0.021)$ & $(0.046)$ & $(0.098)$ & $(0.022)$ & $(0.042)$ & $(0.099)$ & $(0.433)$ & & \\
\hline
\end{tabular}

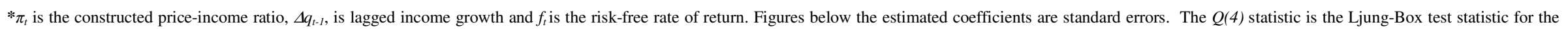

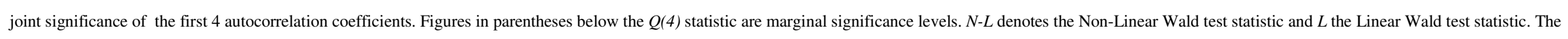

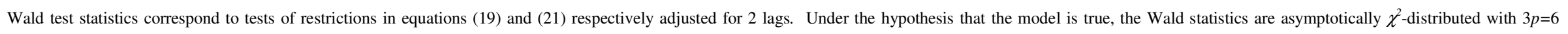
degrees of freedom; marginal significance levels appear in parentheses below the reported Wald statistics. * denotes significance of coefficient estimates at either $1 \%$. $5 \%$ or $10 \%$ levels of significance. 


\section{TAS}

\begin{tabular}{|c|c|c|c|c|c|c|c|c|c|}
\hline $\mathrm{Z}_{t}$ & $\pi_{t-1}$ & $\Delta q_{t-2}$ & $f_{t-1}$ & $\pi_{t-2}$ & $\Delta q_{t-3}$ & $f_{t-2}$ & $Q(4)$ & $\begin{array}{c}N-L \\
\text { Wald }\end{array}$ & L Wald \\
\hline$\pi_{t}$ & $\begin{array}{c}0.855^{*} \\
(0.143)\end{array}$ & $\begin{array}{c}0.576^{*} \\
(0.324)\end{array}$ & $\begin{array}{c}-0.940 \\
(1.288)\end{array}$ & $\begin{array}{c}0.109 \\
(0.149)\end{array}$ & $\begin{array}{c}0.276 \\
(0.288)\end{array}$ & $\begin{array}{c}0.425 \\
(1.240)\end{array}$ & $\begin{array}{c}0.715 \\
(0.949)\end{array}$ & $\begin{array}{c}7.608 \\
(0.268)\end{array}$ & $\begin{array}{c}2.599 \\
(0.857)\end{array}$ \\
\hline \multirow{2}{*}{$\Delta q_{t-1}$} & $\begin{array}{c}0.078 \\
(0.058)\end{array}$ & $\begin{array}{c}-0.550^{*} \\
(0.132)\end{array}$ & $\begin{array}{c}-0.116 \\
(0.524)\end{array}$ & $\begin{array}{c}-0.048 \\
(0.060)\end{array}$ & $\begin{array}{c}-0.238^{*} \\
(0.117)\end{array}$ & $\begin{array}{c}0.509 \\
(0.505)\end{array}$ & $\begin{array}{c}4.028 \\
(0.402)\end{array}$ & & \\
\hline \multirow{2}{*}{$f_{t}$} & $-0.047^{*}$ & -0.006 & $\begin{array}{c}0.261 * \\
(0.013)\end{array}$ & $(0.030)$ & $\begin{array}{c}0.0462^{*} \\
(0.120)\end{array}$ & $\begin{array}{c}0.014) \\
(0.026)\end{array}$ & $\begin{array}{c}0.060 \\
(0.116)\end{array}$ & $\begin{array}{c}3.512 \\
(0.476)\end{array}$ & \\
\hline
\end{tabular}

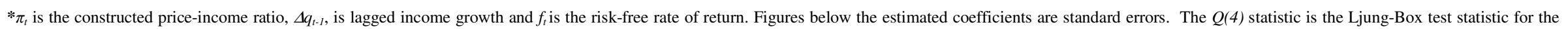

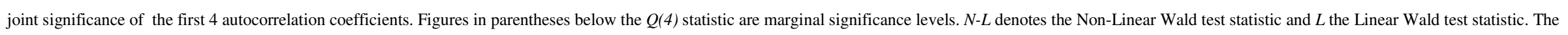

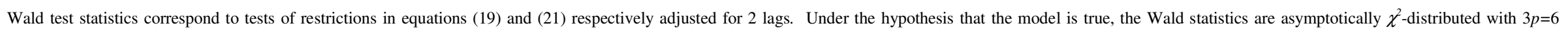
degrees of freedom; marginal significance levels appear in parentheses below the reported Wald statistics. * denotes significance of coefficient estimates at either $1 \%$. $5 \%$ or $10 \%$ levels of significance. 
VIC

\begin{tabular}{|c|c|c|c|c|c|c|c|c|c|}
\hline $\mathrm{z}_{t}$ & $\pi_{t-1}$ & $\Delta q_{t-2}$ & $f_{t-1}$ & $\pi_{t-2}$ & $\Delta q_{t-3}$ & $f_{t-2}$ & $Q(4)$ & $\begin{array}{l}N-L \\
\text { Wald }\end{array}$ & $L$ Wald \\
\hline$\pi_{t}$ & $\begin{array}{c}0.425^{*} \\
(0.095)\end{array}$ & $\begin{array}{r}0.366 \\
(0.366)\end{array}$ & $\begin{array}{l}-0.445 \\
(0.801)\end{array}$ & $\begin{array}{l}0.483^{*} \\
(0.097)\end{array}$ & $\begin{array}{l}-0.109 \\
(0.344)\end{array}$ & $\begin{array}{l}-1.516^{*} \\
(0.807)\end{array}$ & $\begin{array}{c}2.600 \\
(0.627)\end{array}$ & $\begin{array}{l}37.385 \\
(0.000)\end{array}$ & $\begin{array}{l}50.037 \\
(0.000)\end{array}$ \\
\hline$\Delta q_{t-1}$ & $\begin{array}{l}0.065^{*} \\
(0.026)\end{array}$ & $\begin{array}{c}0.114 \\
(0.102)\end{array}$ & $\begin{array}{c}0.472 * \\
(0.223)\end{array}$ & $\begin{array}{c}-0.049 * \\
(0.027)\end{array}$ & $\begin{array}{r}0.063 \\
(0.096)\end{array}$ & $\begin{array}{c}-0.355^{* *} \\
(0.225)\end{array}$ & $\begin{array}{c}1.867 \\
(0.760)\end{array}$ & & \\
\hline$f_{t}$ & $\begin{array}{l}-0.008 \\
(0.012)\end{array}$ & $\begin{array}{c}-0.044 \\
(0.046)\end{array}$ & $\begin{array}{r}0.106 \\
(0.101)\end{array}$ & $\begin{array}{l}-0.006 \\
(0.012)\end{array}$ & $\begin{array}{r}-0.002 \\
(0.043)\end{array}$ & $\begin{array}{l}0.368^{*} \\
(0.102)\end{array}$ & $\begin{array}{c}1.751 \\
(0.781)\end{array}$ & & \\
\hline
\end{tabular}

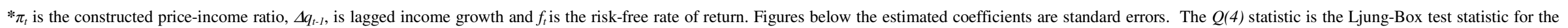

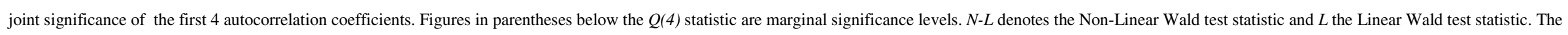

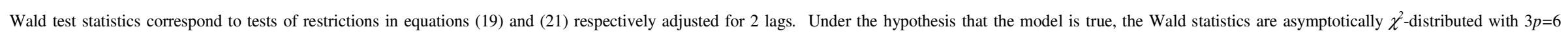
degrees of freedom; marginal significance levels appear in parentheses below the reported Wald statistics. * denotes significance of coefficient estimates at either $1 \%$. $5 \%$ or $10 \%$ levels of significance. 


\section{WA}

\begin{tabular}{|c|c|c|c|c|c|c|c|c|c|}
\hline $\mathrm{z}_{t}$ & $\pi_{t-1}$ & $\Delta q_{t-2}$ & $f_{t-1}$ & $\pi_{t-2}$ & $\Delta q_{t-3}$ & $f_{t-2}$ & $Q(4)$ & $\begin{array}{c}N-L \\
\text { Wald }\end{array}$ & L Wald \\
\hline$\pi_{t}$ & $\begin{array}{l}1.246^{*} \\
(0.112)\end{array}$ & $\begin{array}{l}0.622 * \\
(0.220)\end{array}$ & $\begin{array}{c}-1.679 * \\
(0.656)\end{array}$ & $\begin{array}{c}-0.373^{*} \\
(0.117)\end{array}$ & $\begin{array}{c}-0.043 \\
(0.182)\end{array}$ & $\begin{array}{l}-0.609 \\
(0.695)\end{array}$ & $\begin{array}{c}1.793 \\
(0.773)\end{array}$ & $\begin{array}{l}14.482 \\
(0.025)\end{array}$ & $\begin{array}{l}34.477 \\
(0.000)\end{array}$ \\
\hline$\Delta q_{t-1}$ & $\begin{array}{c}0.059 \\
(0.060)\end{array}$ & $\begin{array}{r}-0.036 \\
(0.118)\end{array}$ & $\begin{array}{l}0.645^{*} \\
(0.352)\end{array}$ & $\begin{array}{c}0.005 \\
(0.062)\end{array}$ & $\begin{array}{c}0.094 \\
(0.098)\end{array}$ & $\begin{array}{c}0.055 \\
(0.373)\end{array}$ & $\begin{array}{c}1.686 \\
(0.793)\end{array}$ & & \\
\hline$f_{t}$ & $\begin{array}{c}-0.014 \\
(0.018)\end{array}$ & $\begin{array}{r}-0.013 \\
(0.035)\end{array}$ & $\begin{array}{l}0.366^{*} \\
(0.105)\end{array}$ & $\begin{array}{c}0.009 \\
(0.018)\end{array}$ & $\begin{array}{c}-0.016 \\
(0.029)\end{array}$ & $\begin{array}{l}0.219^{*} \\
(0.112)\end{array}$ & $\begin{array}{c}8.189 \\
(0.084)\end{array}$ & & \\
\hline
\end{tabular}

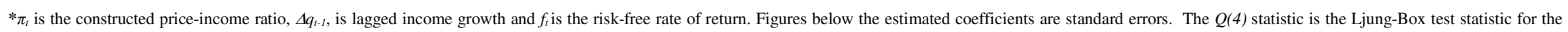

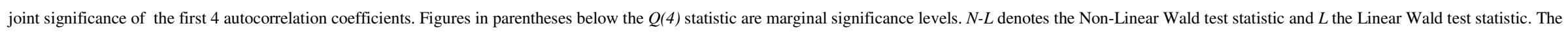

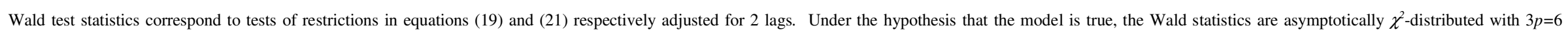
degrees of freedom; marginal significance levels appear in parentheses below the reported Wald statistics. * denotes significance of coefficient estimates at either $1 \% .5 \%$ or $10 \%$ levels of significance. 
Table 4. Actual v Fundamental House Prices*

\begin{tabular}{|c|c|c|c|c|}
\hline & & $\left.-p_{t}^{*}\right)$ & & \\
\hline & Full & riod & & RMSD \\
\hline & Mean & S.D. & & \\
\hline All Australia & -0.003 & 0.055 & 0.102 & 36.22 \\
\hline $\mathrm{ACT}$ & -0.009 & 0.095 & 0.035 & 18.80 \\
\hline NSW & -0.011 & 0.175 & 0.100 & 65.70 \\
\hline NT & -0.012 & 0.103 & 0.089 & 22.95 \\
\hline QLD & -0.005 & 0.078 & 0.003 & 13.00 \\
\hline SA & -0.008 & 0.098 & 0.182 & 20.40 \\
\hline TAS & -0.003 & 0.091 & 0.132 & 21.23 \\
\hline VIC & -0.006 & 0.098 & -0.094 & 26.85 \\
\hline WA & -0.003 & 0.055 & 0.041 & 12.54 \\
\hline $\begin{array}{l}\text { * This table provides } \\
\left(p_{t}-p_{t}^{*}\right) / p_{t}, \\
\text { deviation for the full s } \\
\text { deviation (RMSD) pr } \\
\text { increasing accuracy of }\end{array}$ & $\begin{array}{l}\text { detail for v: } \\
\text { epresents ac } \\
\text { iod and the } \\
\text { measure of } \\
\text { ated series. }\end{array}$ & $\begin{array}{l}\text { n actual ho } \\
p^{*} \text { repres } \\
\text { ence for th } \\
\text { en the act }\end{array}$ & $\begin{array}{l}\text { d our estimate } \\
\text { intal prices. } \\
\text { in the sample, } \\
\text { lated series. I }\end{array}$ & $\begin{array}{l}\text { ntal house prices; } \\
\text { eean and standard } \\
\text { root mean square } \\
\text { values represent }\end{array}$ \\
\hline
\end{tabular}


Table 5. Stationarity of the Non-Fundamental Components of House Prices*

\begin{tabular}{|l|c|}
\hline & Levels \\
\hline & ADF \\
\hline \multirow{2}{*}{ NSW } & -2.031 \\
& $(\mathrm{c}, 0,2)$ \\
\hline & -1.257 \\
VIC & $(\mathrm{c}, 0,1)$ \\
\hline & -2.447 \\
QLD & $(\mathrm{c}, 0,0)$ \\
\hline & -1.990 \\
WA & $(\mathrm{c}, 0,4)$ \\
\hline & -1.207 \\
SA & $(\mathrm{c}, 0,0)$ \\
\hline & -2.477 \\
ACT & $(\mathrm{c}, 0,2)$ \\
\hline & First Differences \\
\hline & -4.847 \\
NSW & $(\mathrm{c}, 0,1)$ \\
\hline \multirow{3}{*}{ VIC } & -15.101 \\
\hline \multirow{3}{*}{ QLD } & $(\mathrm{c}, 0,0)$ \\
\hline & -10.623 \\
WA & $(\mathrm{c}, 0,0)$ \\
\hline & -9.697 \\
SA & $(\mathrm{c}, 0,1)$ \\
\hline & -10.849 \\
ACT & $(\mathrm{c}, 0,0)$ \\
\hline & -13.247 \\
& $(\mathrm{c}, 0,0)$ \\
\hline
\end{tabular}

*See notes to first panel of Table $1 \mathrm{~b}$.

Table 6. Cointegration in Non-Fundamental Components of State House Prices*

\begin{tabular}{|c|c|c|c|c|}
\hline \multirow[b]{2}{*}{ Variable } & \multicolumn{2}{|c|}{ Johansen Tests } & \multirow{2}{*}{$\begin{array}{c}\text { Model } \\
\text { specification }\end{array}$} & \multirow[b]{2}{*}{ Lags } \\
\hline & Trace & Eigenvalue & & \\
\hline $\begin{array}{l}\text { Non- } \\
\text { Fundamental } \\
\text { Components }\end{array}$ & 1 & 1 & $\begin{array}{l}\text { intercepts, no } \\
\text { trend }\end{array}$ & 2 \\
\hline
\end{tabular}


Table 7. Long-run Response of Non-Fundamental Components of State House Prices to a One Unit Shock (1\% increase) to Non-Fundamental Components of Other State House Prices

\begin{tabular}{|c||c|c|c|c|c|c|}
\hline $\begin{array}{c}\text { Shocked } \\
\text { Variable }\end{array}$ & $\begin{array}{c}\text { Response } \\
\text { of NSW }\end{array}$ & $\begin{array}{c}\text { Response } \\
\text { of VIC }\end{array}$ & $\begin{array}{c}\text { Response } \\
\text { of QLD }\end{array}$ & $\begin{array}{c}\text { Response } \\
\text { of WA }\end{array}$ & $\begin{array}{c}\text { Response } \\
\text { of SA }\end{array}$ & $\begin{array}{c}\text { Response } \\
\text { of ACT }\end{array}$ \\
\hline NSW & 0.6 & -0.2 & 0.2 & zero & 0.3 & 0.3 \\
\hline VIC & 0.2 & 0.5 & -0.18 & zero & -0.09 & -0.19 \\
\hline QLD & -0.4 & 0.2 & 0.6 & 0.15 & -0.08 & -0.1 \\
\hline WA & -1.0 & 0.2 & 0.2 & 0.5 & 0.38 & 0.1 \\
\hline SA & 1.0 & 0.2 & 0.12 & zero & 0.45 & -0.11 \\
\hline ACT & -0.2 & zero & 0.1 & -0.1 & 0.22 & 1 \\
\hline
\end{tabular}




\begin{tabular}{|c|c|c|}
\hline \multicolumn{3}{|c|}{$\begin{array}{l}\text { ECONOMICS DISCUSSION PAPERS } \\
2009\end{array}$} \\
\hline $\begin{array}{l}\text { DP } \\
\text { NUMBER }\end{array}$ & AUTHORS & TITLE \\
\hline 09.01 & Le, A.T. & $\begin{array}{l}\text { ENTRY INTO UNIVERSITY: ARE THE CHILDREN OF } \\
\text { IMMIGRANTS DISADVANTAGED? }\end{array}$ \\
\hline 09.02 & $\mathrm{Wu}, \mathrm{Y}$ & CHINA'S CAPITAL STOCK SERIES BY REGION AND SECTOR \\
\hline 09.03 & Chen, M.H. & $\begin{array}{l}\text { UNDERSTANDING WORLD COMMODITY PRICES RETURNS, } \\
\text { VOLATILITY AND DIVERSIFACATION }\end{array}$ \\
\hline 09.04 & Velagic, R. & UWA DISCUSSION PAPERS IN ECONOMICS: THE FIRST 650 \\
\hline 09.05 & McLure, M. & $\begin{array}{l}\text { ROYALTIES FOR REGIONS: ACCOUNTABILITY AND } \\
\text { SUSTAINABILITY }\end{array}$ \\
\hline 09.06 & Chen, A. and Groenewold, N. & $\begin{array}{l}\text { REDUCING REGIONAL DISPARITIES IN CHINA: AN } \\
\text { EVALUATION OF ALTERNATIVE POLICIES }\end{array}$ \\
\hline 09.07 & Groenewold, N. and Hagger, A. & $\begin{array}{l}\text { THE REGIONAL ECONOMIC EFFECTS OF IMMIGRATION: } \\
\text { SIMULATION RESULTS FROM A SMALL CGE MODEL. }\end{array}$ \\
\hline 09.08 & Clements, K. and Chen, D. & AFFLUENCE AND FOOD: SIMPLE WAY TO INFER INCOMES \\
\hline 09.09 & Clements, K. and Maesepp, M. & A SELF-REFLECTIVE INVERSE DEMAND SYSTEM \\
\hline 09.10 & Jones, C. & $\begin{array}{l}\text { MEASURING WESTERN AUSTRALIAN HOUSE PRICES: } \\
\text { METHODS AND IMPLICATIONS }\end{array}$ \\
\hline 09.11 & Siddique, M.A.B. & $\begin{array}{l}\text { WESTERN AUSTRALIA-JAPAN MINING CO-OPERATION: AN } \\
\text { HISTORICAL OVERVIEW }\end{array}$ \\
\hline 09.12 & Weber, E.J. & $\begin{array}{l}\text { PRE-INDUSTRIAL BIMETALLISM: THE INDEX COIN } \\
\text { HYPTHESIS }\end{array}$ \\
\hline 09.13 & McLure, M. & $\begin{array}{l}\text { PARETO AND PIGOU ON OPHELIMITY, UTILITY AND } \\
\text { WELFARE: IMPLICATIONS FOR PUBLIC FINANCE }\end{array}$ \\
\hline 09.14 & Weber, E.J. & $\begin{array}{l}\text { WILFRED EDWARD GRAHAM SALTER: THE MERITS OF A } \\
\text { CLASSICAL ECONOMIC EDUCATION }\end{array}$ \\
\hline 09.15 & Tyers, R. and Huang, L. & $\begin{array}{l}\text { COMBATING CHINA'S EXPORT CONTRACTION: FISCAL } \\
\text { EXPANSION OR ACCELERATED INDUSTRIAL REFORM }\end{array}$ \\
\hline 09.16 & $\begin{array}{l}\text { Zweifel, P., Plaff, D. and } \\
\text { Kühn, J. }\end{array}$ & $\begin{array}{l}\text { IS REGULATING THE SOLVENCY OF BANKS COUNTER- } \\
\text { PRODUCTIVE? }\end{array}$ \\
\hline 09.17 & Clements, K. & THE PHD CONFERENCE REACHES ADULTHOOD \\
\hline 09.18 & McLure, M. & $\begin{array}{l}\text { THIRTY YEARS OF ECONOMICS: UWA AND THE WA } \\
\text { BRANCH OF THE ECONOMIC SOCIETY FROM } 1963 \text { TO } 1992\end{array}$ \\
\hline 09.19 & Harris, R.G. and Robertson, P. & $\begin{array}{l}\text { TRADE, WAGES AND SKILL ACCUMULATION IN THE } \\
\text { EMERGING GIANTS }\end{array}$ \\
\hline 09.20 & $\begin{array}{l}\text { Peng, J., Cui, J., Qin, F. and } \\
\text { Groenewold, N. }\end{array}$ & STOCK PRICES AND THE MACRO ECONOMY IN CHINA \\
\hline 09.21 & Chen, A. and Groenewold, N. & $\begin{array}{l}\text { REGIONAL EQUALITY AND NATIONAL DEVELOPMENT IN } \\
\text { CHINA: IS THERE A TRADE-OFF? }\end{array}$ \\
\hline
\end{tabular}




\begin{tabular}{|c|c|c|}
\hline \multicolumn{3}{|c|}{$\begin{array}{c}\text { ECONOMICS DISCUSSION PAPERS } \\
2010\end{array}$} \\
\hline $\begin{array}{l}\text { DP } \\
\text { NUMBER }\end{array}$ & AUTHORS & TITLE \\
\hline 10.01 & Hendry, D.F. & $\begin{array}{l}\text { RESEARCH AND THE ACADEMIC: A TALE OF } \\
\text { TWO CULTURES }\end{array}$ \\
\hline 10.02 & McLure, M., Turkington, D. and Weber, E.J. & A CONVERSATION WITH ARNOLD ZELLNER \\
\hline 10.03 & $\begin{array}{l}\text { Butler, D.J., Burbank, V.K. and } \\
\text { Chisholm, J.S. }\end{array}$ & $\begin{array}{l}\text { THE FRAMES BEHIND THE GAMES: PLAYER'S } \\
\text { PERCEPTIONS OF PRISONER'S DILEMMA, } \\
\text { CHICKEN, DICTATOR, AND ULTIMATUM GAMES }\end{array}$ \\
\hline 10.04 & Harris, R.G., Robertson, P.E. and Xu, J.Y. & $\begin{array}{l}\text { THE INTERNATIONAL EFFECTS OF CHINA'S } \\
\text { GROWTH, TRADE AND EDUCATION BOOMS }\end{array}$ \\
\hline 10.05 & Clements, K.W., Mongey, S. and Si, J. & $\begin{array}{l}\text { THE DYNAMICS OF NEW RESOURCE PROJECTS } \\
\text { A PROGRESS REPORT }\end{array}$ \\
\hline 10.06 & Costello, G., Fraser, P., Groenewold, N. & $\begin{array}{l}\text { HOUSE PRICES, NON-FUNDAMENTAL } \\
\text { COMPONENTS AND INTERSTATE SPILLOVERS: } \\
\text { THE AUSTRALIAN EXPERIENCE }\end{array}$ \\
\hline 10.07 & Clements, $\mathrm{K}$. & $\begin{array}{l}\text { REPORT OF THE } 2009 \text { PHD CONFERENCE IN } \\
\text { ECONOMICS AND BUSINESS }\end{array}$ \\
\hline 10.08 & Robertson, P.E. & $\begin{array}{l}\text { INVESTMENT LED GROWTH IN INDIA: HINDU } \\
\text { FACT OR MYTHOLOGY? }\end{array}$ \\
\hline 10.09 & Fu, D., Wu, Y., Tang, Y. & $\begin{array}{l}\text { THE EFFECTS OF OWNERSHIP STRUCTURE AND } \\
\text { INDUSTRY CHARACTERISTICS ON EXPORT } \\
\text { PERFORMANCE }\end{array}$ \\
\hline 10.10 & $\mathrm{Wu}, \mathrm{Y}$. & $\begin{array}{l}\text { INNOVATION AND ECONOMIC GROWTH IN } \\
\text { CHINA }\end{array}$ \\
\hline 10.11 & Stephens, B.J. & $\begin{array}{l}\text { THE DETERMINANTS OF LABOUR FORCE } \\
\text { STATUS AMONG INDIGENOUS AUSTRALIANS }\end{array}$ \\
\hline
\end{tabular}

